\title{
Ethnic food culture of Chhattisgarh state of India
}

\author{
Akhilesh Shukla* ${ }^{*}$
}

\begin{abstract}
Chhattisgarh state is situated in the central part of India and is also known as the 'Bowl of rice'. Paddy is the principal crop of this state, and rice is the staple diet of the people. The state largely maintains its ethnic food culture as most of its population continues to live within rural and tribal areas. The state has nearly $44 \%$ of forest cover which serves as a decent source of food. People here prefer a vegetarian diet, and over 70 varieties of leaves, 25 varieties of tubers and roots are used here as vegetables. The present article is an attempt to explore the ethnic food culture of Chhattisgarh and to provide information about rice and non-rice-based traditional recipes, sweet dishes, leafy vegetables, tubers and roots which are consumed here. Irrespective of all the modern changes in food habits, the people of Chhattisgarh still preserve their traditional food culture.
\end{abstract}

Keywords: Food culture, Food ways, Traditional food practices, Indian diet, Vegetarian diet

\section{Introduction}

\section{About Chhattisgarh and its food culture}

Chhattisgarh is a state in the central part of India. The word 'Chhattis' means thirty-six and 'Garh' means fort, so the name Chhattisgarh symbolizes the number of forts in the region. It is also known as the 'Rice Bowl' of Central India, and nearly $70 \%$ of its population is engaged in agriculture. Paddy is the principal crop of the state [1] which also constitutes the main diet of people here. It is evident that with increase in urbanization there is a change from traditional eating behaviour of people towards the fastfood culture [2,3]. But in Chhattisgarh, approximately $80 \%$ of the population lives in rural areas [4], as a result of which its traditional heritage is still alive and the food habits are majorly unchanged. Chhattisgarhi cuisine has a wide range of delicious dishes which are nutritious and healthy. As the state has a dense forest cover, the rural and tribal people also collect roots, tubers, leaves, flowers and fruits from the forest as their food supplements.

*Correspondence: an2akhilesh@gmail.com Department of Samhita-Siddhanta, Govt. Ayurveda College, Raipur, Chhattisgarh, India
These give the traditional Chhattisgarhi cuisine a unique natural flavour and health benefits. More than 70 varieties of leaves and nearly 25 varieties of tubers and roots are consumed here as vegetables $[5,6]$. This article explores the rice and non-rice-based traditional recipes of Chhattisgarh cuisine and provides details of leaves, tubers and roots which are consumed here. The food culture of Chhattisgarh is predominantly vegetarian, and it utilizes the available natural resources to fulfil the nutritional needs of the people and to make it delicious.

\section{Advantages of traditional food culture}

At present, about $90 \%$ of the global food production comes from less than 30 species [7]. Natural sources are not well utilized and gradually quite a few varieties of grains and vegetables are going out of cultivation. Because of non-utilization, the people are also losing knowledge about their dietary and medicinal properties. The existing food culture of Chhattisgarh indicates to us, the ways to look towards naturally available resources and how to make use of it for better nutrition and health status.

Most of the vegetables presently consumed by Indian people are not native to India, such as the tomato original author(s) and the source, provide a link to the Creative Commons licence, and indicate if changes were made. The images or other third party material in this article are included in the article's Creative Commons licence, unless indicated otherwise in a credit line to the material. If material is not included in the article's Creative Commons licence and your intended use is not permitted by statutory regulation or exceeds the permitted use, you will need to obtain permission directly from the copyright holder. To view a copy of this licence, visit http://creativecommons.org/licenses/by/4.0/. 
(Solanum lycopersicum) which is one of the most widely cultivated vegetable crops in India and the world, actually originated from the Andean region $[8,9]$. It came to India through the Portuguese explorers during the early sixteenth century [10]. Similarly, the potato which is very popular vegetable in India actually has its origins in the border between Peru and Bolivia. By the end of the sixteenth century, potatoes were introduced in many European countries and from there arrived in India in the early seventeenth century [11]. Cauliflower, which is now cultivated throughout the country, was first introduced in 1822 by Dr. Jemson from England, who was in-charge of Company Bagh, Saharanpur, Uttar Pradesh [12]. Many other fruits and vegetables which are consumed now are foreign, but we have adopted them very well in to our present food culture. Chillies, spinach, cabbage are few examples and the list is long [13]. Many of these vegetables are now available throughout the year with the help of modern techniques. The practice of seasonal food consumption has practically vanished because of this. The consequences of this may not be visible immediately yet it is evident that it is not the right way to consume food. Traditional food is designed based on the seasonal changes after thorough understanding of the interaction between man and the environment.

Globally, majority of people consistently consume less than the daily recommended fruit and vegetable requirement [14]. The traditional Indian diet has a large number of fruits and vegetables in it. India ranks second in fruit and vegetable production in the world, after China [15]. Fruits and vegetables are a key food group providing essential vitamins and minerals, and their intake is particularly important in settings where micronutrient deficiencies are widespread, such as in India [16]. Chhattisgarh food culture is the way forward to adopt ecofriendly practices and utilize available natural resources to enrich our daily diet. The processing and preparation of ethnic foods not only validate the creativity and treasure of food heritage of the local population but also their incredible mastery in maintaining the existence of the ecosystem as a whole [17].

Public health status is largely dependent upon their dietary behaviours. Traditional food culture has gradually evolved along with the development of the human race. It is based on the geographical situation, climatic condition, seasonal changes, type of soil, source of water, forest region, agriculture, immigrants, influence of invaders and working patterns of the people of the region. Traditional food culture is an experiential system which takes generations to come to its shape. The role of food is not just limited to pacify hunger, but it has a broader significance and plays a vital role in almost every aspect of human life, be it family, social relations, festivals or sacred rituals. Traditional food is wholesome for maintaining and protecting health and providing optimum nutrition to the people of that region. In the name of globalization, adopting food patterns that are foreign to this region is unscientific and could be harmful for health. The shift from traditional to the western dietary pattern has become the leading cause of the growing burden of non-communicable or lifestyle-related diseases and in the year 2015, the Global Burden of Disease study identified unhealthy diet as the leading cause of early mortality worldwide $[18,19]$. Every traditional food culture carries a long history and is the safest food to be consumed by the people of that locality.

\section{What is unique in Chhattisgarhi cuisine}

Though rice is the staple food of Chhattisgarh people, a regular Chhattisgarhi meal also comprises of pulses, seasonal green leafy vegetables, tubers and roots. As the state is rich with natural forest cover, the rural and tribal people have developed the wisdom to fulfil their needs from the available forest resources. This is very evident in the ethnic food culture of Chhattisgarh.

\section{Methods}

An ethnographic study was conducted between February 2017 and February 2020, using face-to-face fieldwork, to understand food culture of Chhattisgarh in depth. Through semi-structured interviews, open-ended questions were asked regarding the type of food preferably consumed, how it is prepared, seasonal changes in food consumption and the expected health benefits of various food items. Wherever need was felt specific details were further asked. Re-visits were also done where ever required. In Chhattisgarh, 'Haats' (local village market) are held in villages, on different days of the week in a rotational pattern. Visits to these local markets and interacting with the people there provided a glimpse of various grains and vegetables cultivated or collected locally. School teachers and village officers helped to connect and friendly communicate with the local people. At least 124 villages were visited and 140 females and 120 males were interviewed after written informed consent. Both audio recording and transcribing were used as per the situations. The collected information was further crossreferenced for their botanical source and published scientific evidences both in modern and Indian system of medicines.

\section{Rice-based traditional recipes of Chhattisgarh}

Angakar Roti - It is a thick flatbread (Roti) made of rice flour and is cooked over burning charcoal. Angar is burning charcoal, and because of this cooking method, it derives the name 'Angakar Roti' (shown in Fig. 1). 


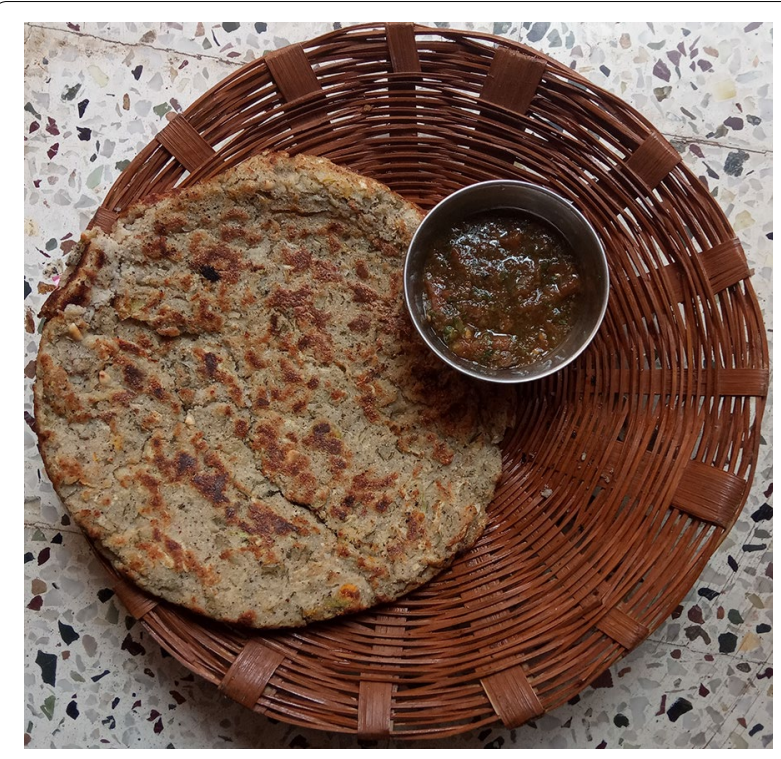

Fig. 1 Angakar Roti

Alternatively, wheat (Triticum aestivum) flour is also used to prepare it and is a common dish in many northern states of India. In southern states Akki Roti is popular which is cooked on hot griddle (tawa) after smearing oil on it.

Chausela - Chausela (shown in Fig. 2) is salty poori made of rice flour. The dough is prepared by mixing rice flour, carom seeds, salt and warm water. Small flattened balls are made from the dough and rolled into round pooris that are to be fried in hot ghee or oil.

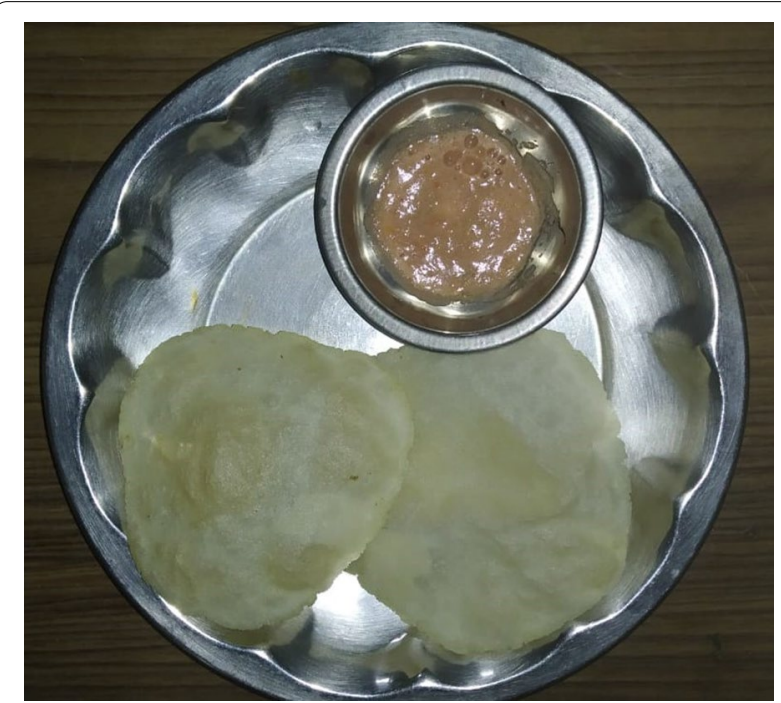

Fig. 2 Chausela
Cheela - Cheela (shown in Fig. 3) is a salted thin rice pancake prepared from rice batter. Freshly harvested rice is preferred. It can also be prepared with flour of Moong (green gram) or Urad (black gram) or Besan (Bengal gram) flour. It seems similar to the Dosa of South India and is often called Chhattisgarhi Dosa. Dosa is a fermented product prepared from rice and black gram batter [20], whereas Cheela is prepared without fermentation. Usually, it is consumed in the morning with spicy Chutney.

Dhuska - Dhuska is a thick Roti (shown in Fig. 4) made of rice, also called Mota Roti. The dough is prepared with one-part cooked rice, two parts of rice flour and salt to taste. A ball of dough is manually flattened and baked over a heated Tawa (iron pan). A small amount of ghee or oil is also used while cooking.

Faraa - Faraa is a steamed rice preparation (shown in Fig. 5). Rice flour is mixed with warm water and a pinch of salt to prepare the dough. Soaked black gram or green gram paste mixed with spices such as ginger, coriander, cumin, black pepper, turmeric can be used as stuffing. It can be made without the stuffing as well. For steam cooking, first heat 2 to 3 cups of water in a vessel, place a strainer over it and grease it with a little oil or ghee. Place some Faraa over the strainer and cook for 10 to $12 \mathrm{~min}$ on medium flame while covering it. It is an oil free and delicious food. To make it spicy and little crispy, Faraa can also be fried in a little oil along with mustard seeds, cumin seeds, sesame seeds, ginger, garlic and green chilli.

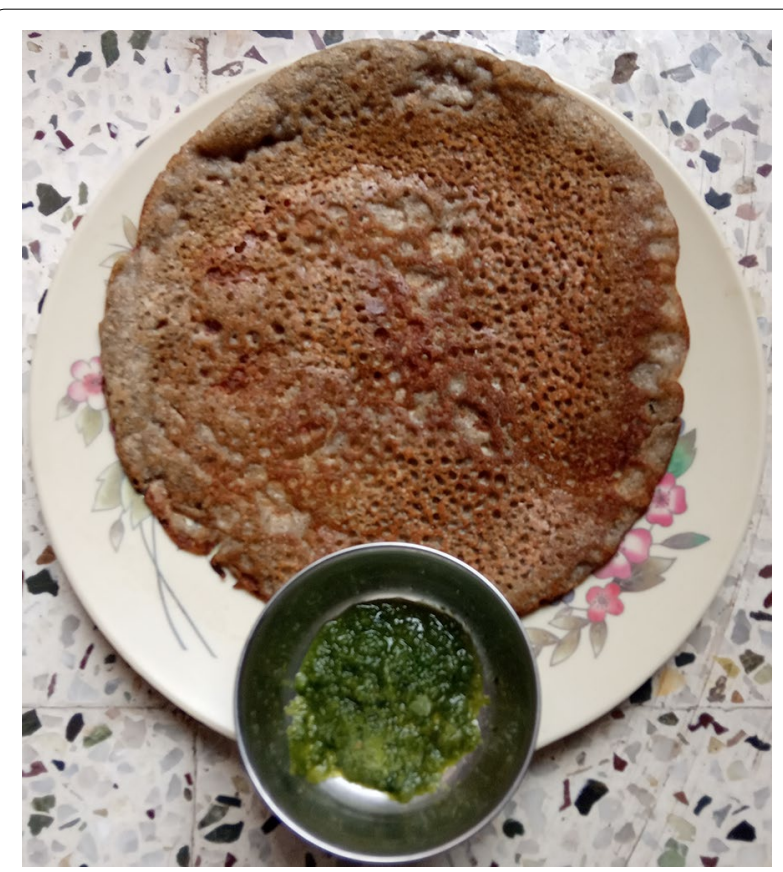

Fig. 3 Cheela 


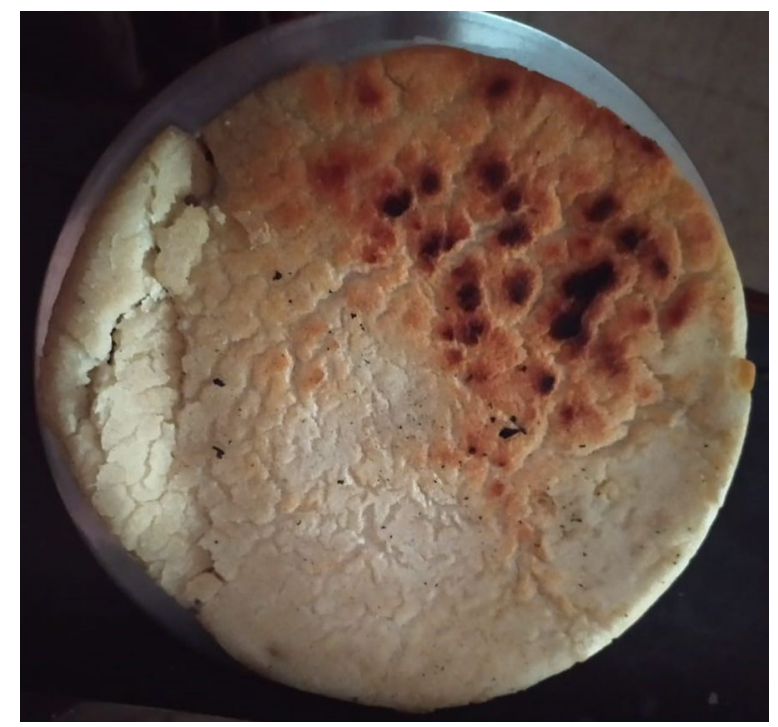

Fig. 4 Dhuska

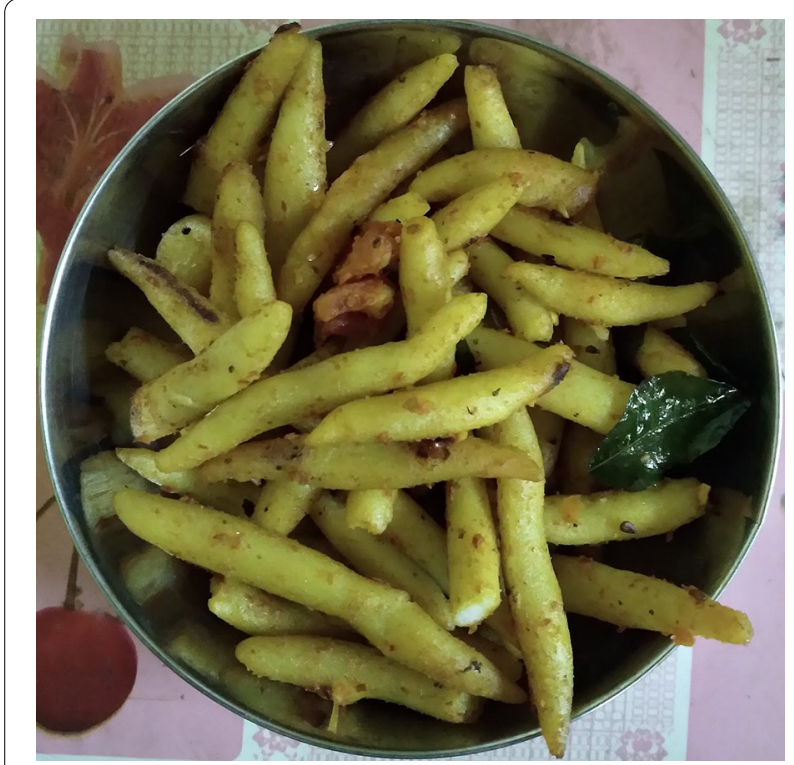

Fig. 5 Fara

Muthia - Muthia (shown in Fig. 6) is made of boiled rice, rice flour, sesame seeds, garlic, coriander leaves, spices and salt. Muthia means fist and the dish got its name from the cooking method that requires the hand to be held in a fist to prepare it. It is mainly prepared during the winter season and is made either by frying or steaming.

$P e j$ - It is a liquid or semisolid preparation of rice similar to rice gruel (shown in Fig. 7). A small quantity of rice is cooked with a larger quantity of water and is

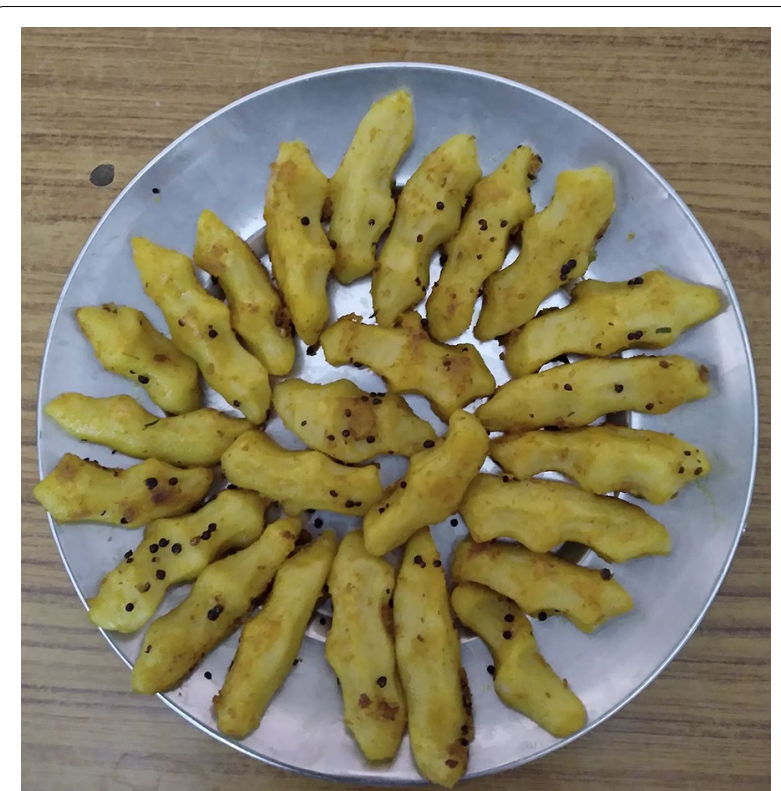

Fig. 6 Muthia

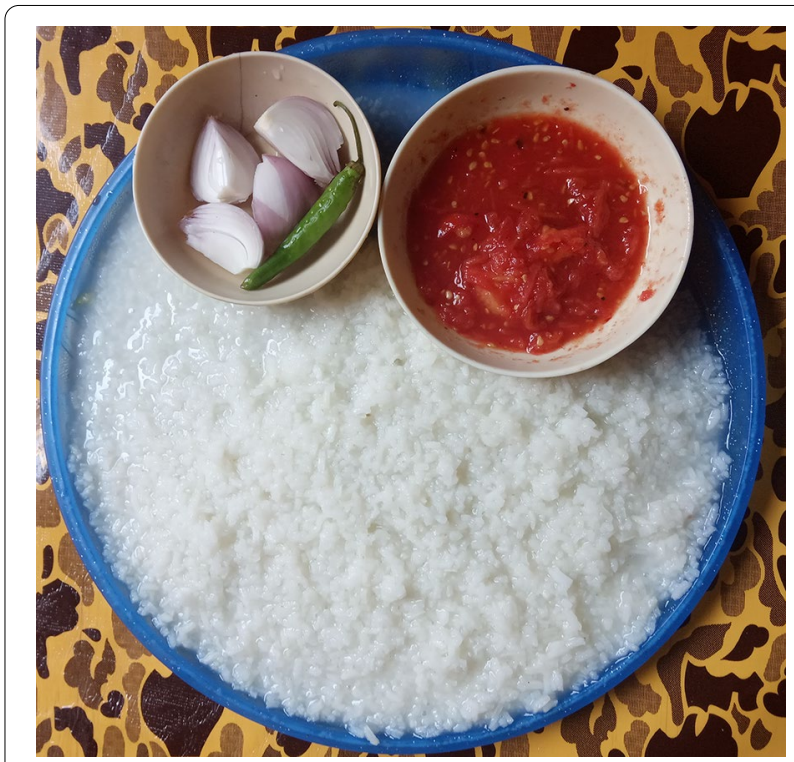

Fig. 7 Pej

consumed with onion pieces and pickle or spicy chutney. The quantity of water varies as per the season, e.g., during summer, liquid portion is more to keep the person hydrated. This preparation is consumed throughout the year, especially in the morning hours. During ill health it is advised to consume Pej as it is easily digestible. Pej is very similar to the rice preparations 
explained in Ayurveda texts in the name of Manda, Peya and Yavagu [21].

\section{Non-rice preparations of Chhattisgarh}

Aamat - Aamat (shown in Fig. 8) is considered as Sambhar (lentil-based liquid extract) of Chhattisgarh. Aamat means sour in local dialect. It is a sour and spicy soup, very popular in the Bastar district of Chhattisgarh. Aamat comprises of a variety of vegetables along with bamboo shoots and spices such as asafoetida, ginger, cumin, coriander and garlic. It is prepared on special occasions such as when guest or relatives visit home. It is a spicy, nutritious and delicious preparation and can be taken along with cooked rice or Roti/Chapati.

Bara - Bara (shown in Fig. 9) of Chhattisgarh is similar to the South Indian Vada/Vadai made from Urad (black gram) batter. Small quantities of chopped chillies, fresh ginger and coriander, chopped onion (occasionally) are mixed with Bara batter. Traditionally, it is served on Dona (leaves folded up in the shape of a cup) with spicy chutney made of green chillies, tomato and coriander leaves.

Bafauri - Bafauri (shown in Fig. 10) is a famous dish of Chhattisgarh state made from Chana Dal (split chickpeas) batter. Various spices such as chopped green chilli, ginger, onion, coriander leaves, garlic paste and a little turmeric powder are added to the mixture. The dough

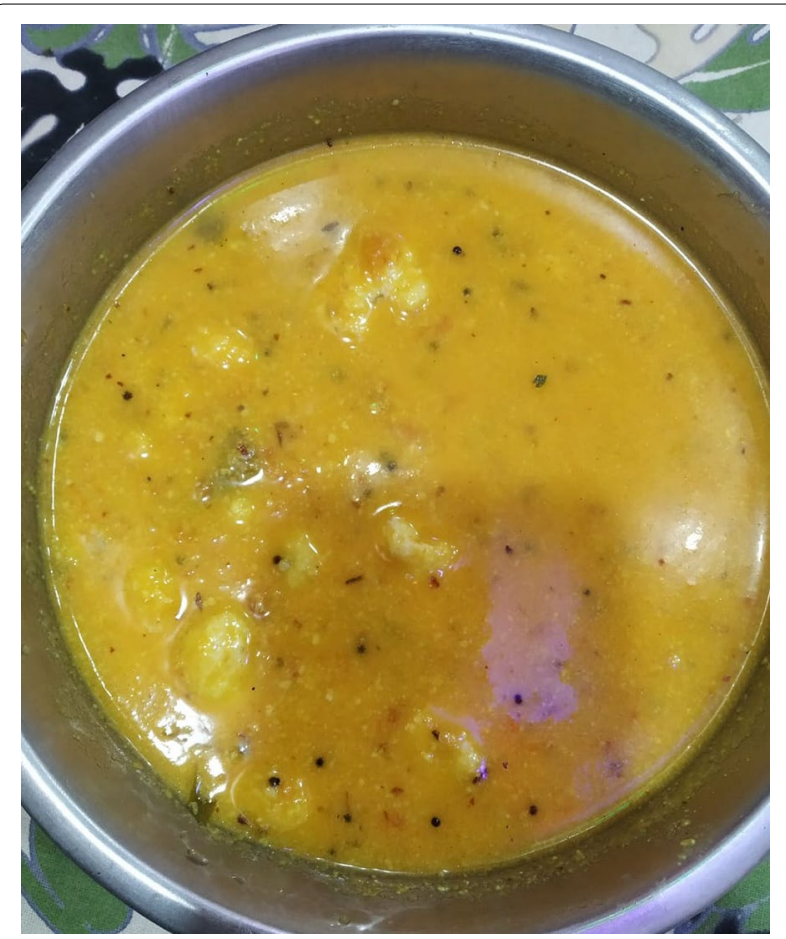

Fig. 8 Aamat

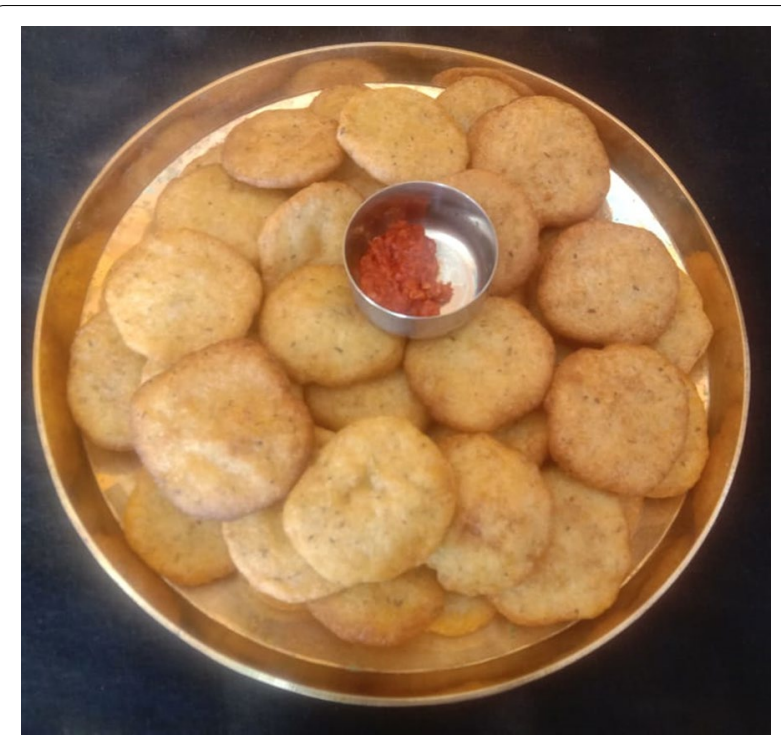

Fig. 9 Bara

is mixed to prepare small balls and is steamed for 15 to 20 min.

Dubaki Kadhi - Kadhi is a sour and spicy curry made of buttermilk and Besan (gram flour) (shown in Fig. 11). It is popular in many Indian states such as Maharashtra, Punjab, Gujarat etc. In Dubaki Kadhi of Chhattisgarh, round balls of Urad paste are added to boiling Kadhi. Apart from Dubaki Kadhi, there are many other varieties of Kadhi popular in the state such as Bhindi (Okra/ ladyfingers) Kadhi, Kochai or Aravi (tubers of Colocasia esculenta (L.) Schott) Kadhi, Lauki (bottle gourd) Kadhi.

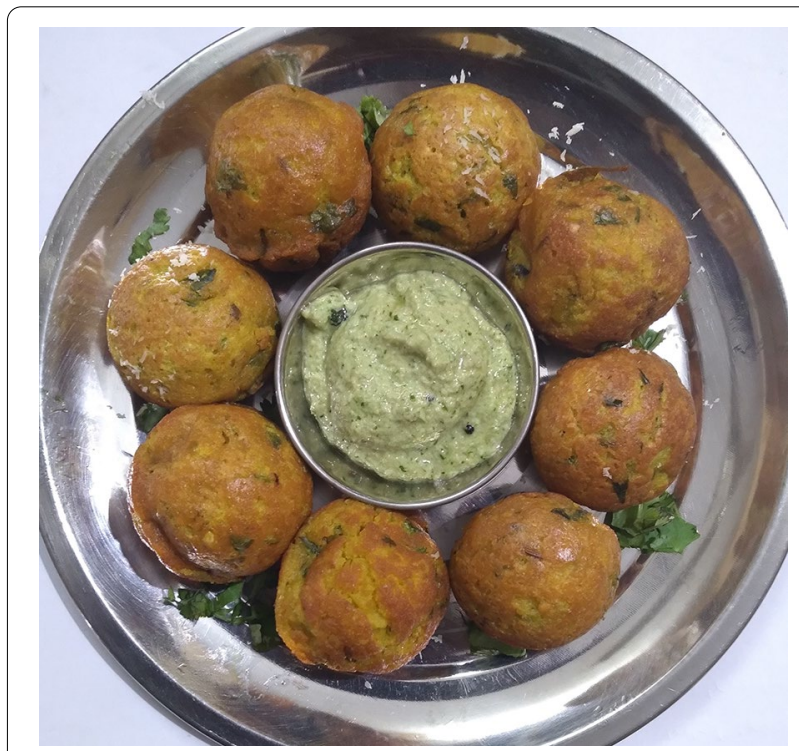

Fig. 10 Bafauri 


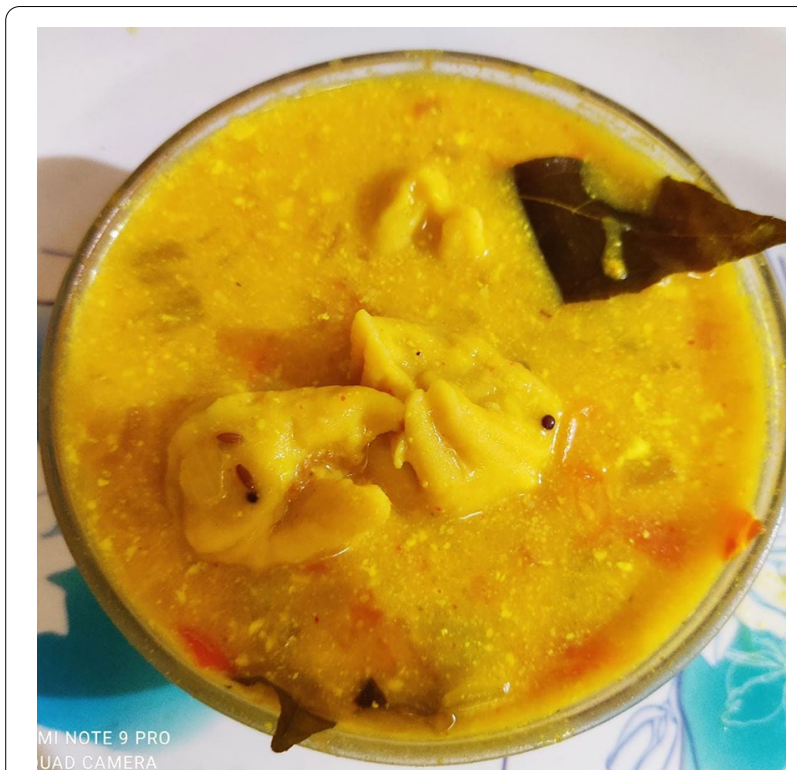

Fig. 11 Dubaki Kadhi

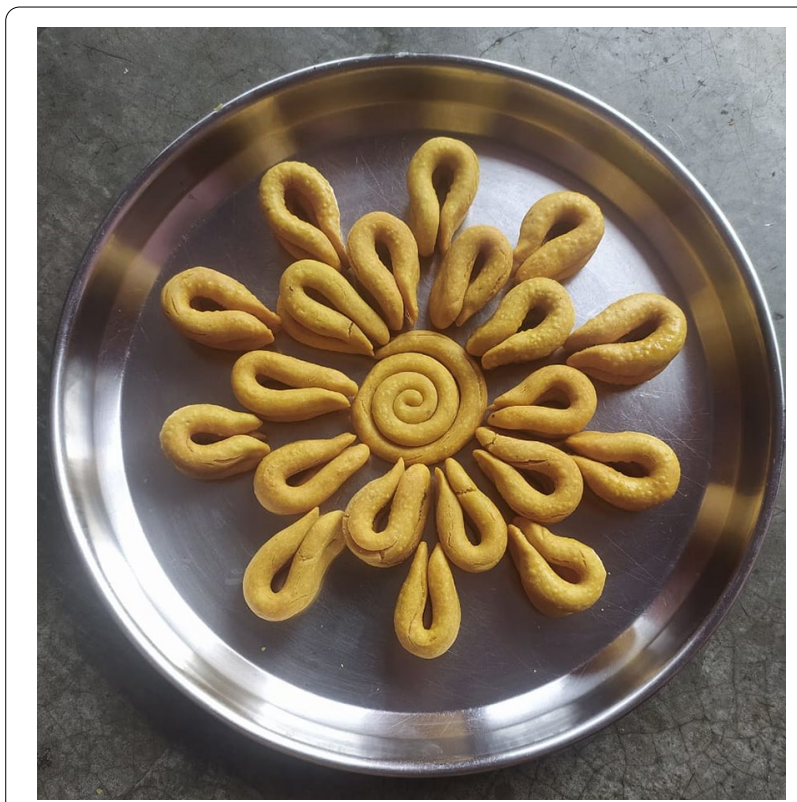

Fig. 12 Thethari

Thethari - Thethari is a deep-fried snack made of gram flour and rice flour (shown in Fig. 12). It is mixed with salt and spices such as cumin seed, Ajwain and red chilli powder. The dough is kneaded and small pieces of it is taken and rolled into different spiral shapes and fried in oil.

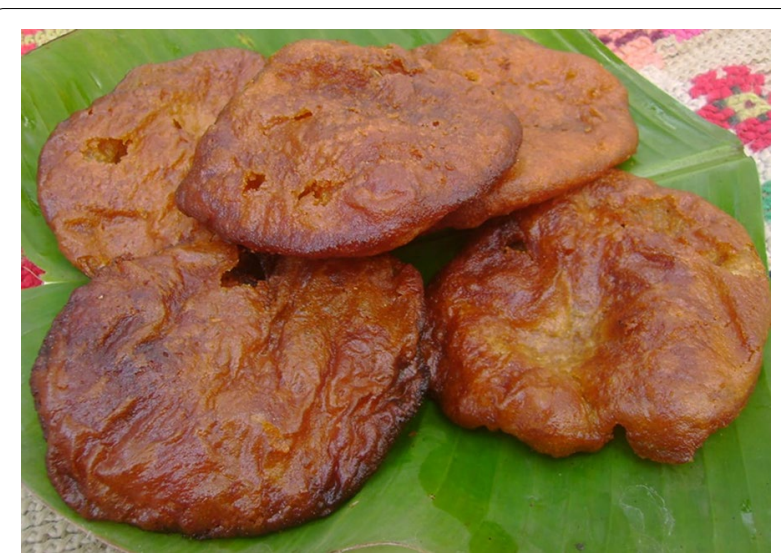

Fig. 13 Anarsa

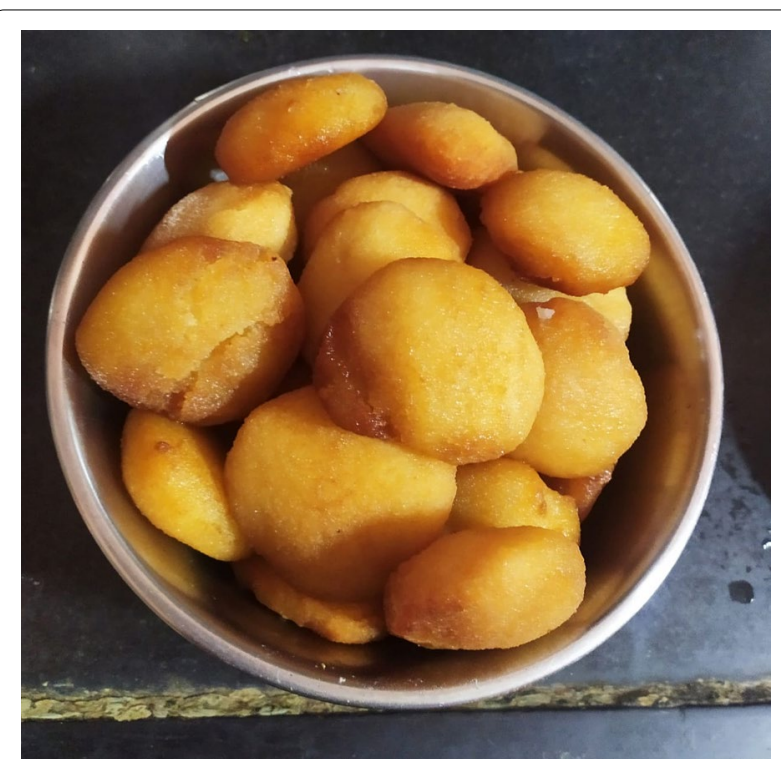

Fig. 14 Dahrauri

\section{Sweet Dishes of Chhattisgarh}

Anarasa - Anarasa is a semi-hard, deep-fried dish made of rice flour, jaggery and sesame seeds (shown in Fig. 13). It is prepared by soaking rice in water overnight. This soaked rice is powdered when still moist and is mixed with jaggery to prepare a dough, and a small quantity of sesame seeds are added to it. The small flat and round pieces of dough are then fried in ghee.

Dehrauri - Dehrauri is a deep-fried soft ball made of rice, curd and jaggery (shown in Fig. 14). Rice is first soaked in water for a few hours and ground coarsely. Curd is then added, mixed well and left for slight fermentation. Flat disc or small balls are prepared and fried in ghee till they turn dark brown in colour. Jaggery syrup is 


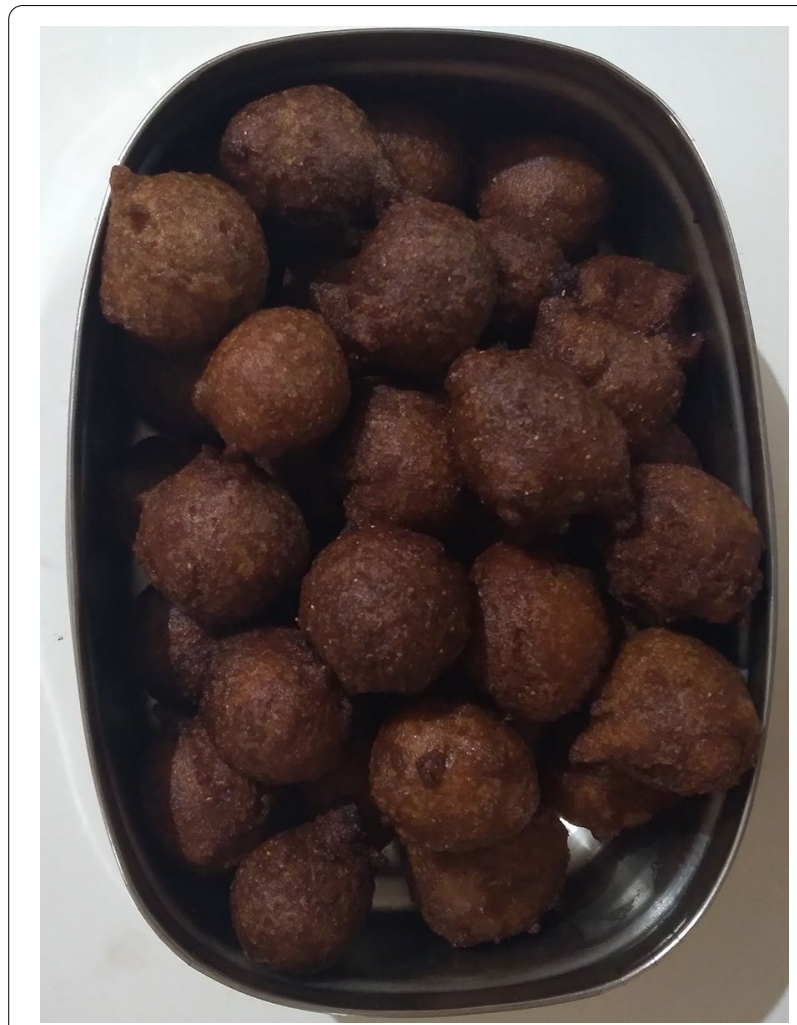

Fig. 15 Gulgula

prepared separately with little cardamom powder. The fried disc/balls are then soaked in jaggery syrup.

Gulgula - Gulgula (shown in Fig. 15) is a brown, deepfried, sweet ball made of wheat flour, jaggery, grated coconut, cardamom powder, Saunf (Foeniculum vulgare) powder and ghee. Dough is prepared using jaggery syrup, wheat flour and all other ingredients. Small balls measuring 2 to $3 \mathrm{~cm}$ in diameter are prepared and fried in ghee. It is delicious but heavy for digestion and is mostly prepared during the winter season or festivals.

Khurmi - Khurmi (shown in Fig. 16) is a fried sweet snack made of wheat flour, jaggery or sugar and ghee. To make the dish, wheat flour is kneaded with little ghee and a dough is prepared by adding jaggery or sugar mixed water. Small pieces of dough are rolled and fried in ghee on moderate flame. It can be easily stored for 2 to 3 weeks and is prepared mostly during the Deepawali festival.

Tikhur Sweets - Tikhur (Curcuma angustifolia) is a rhizomatous herb also known as white turmeric or East Indian Arrowroot. The fresh rhizomes of Tikhur are used for preparation of starchy flour which also has medicinal value. The rhizome pulp is a remedy for fever, joint pain, leucorrhoea, renal stone, inflammatory conditions, bone fracture and abdominal diseases such as peptic ulcer, indigestion, stomach ache. It is even used as a

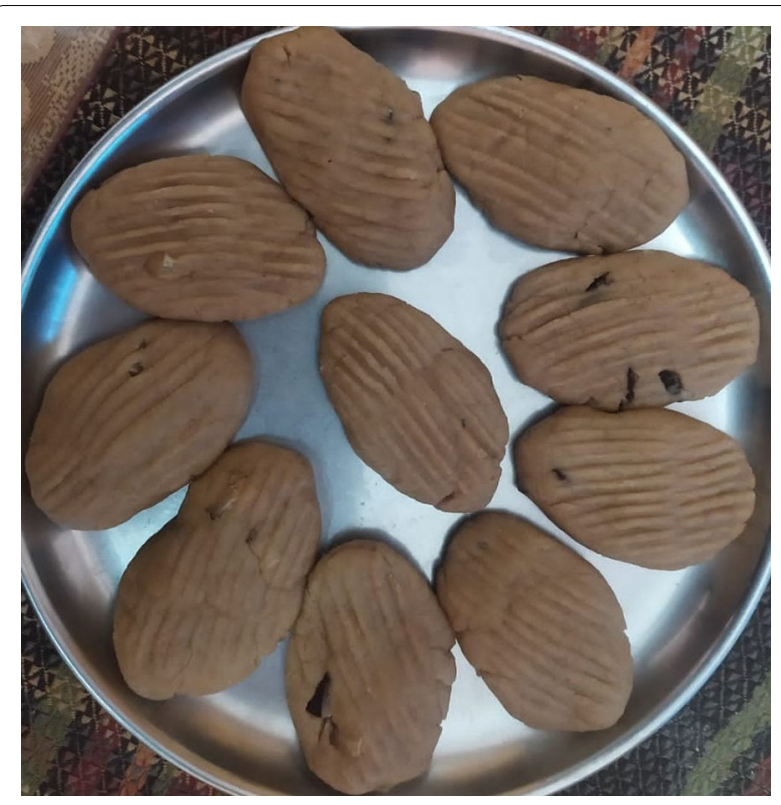

Fig. 16 Khurmi

supplementary diet for children in the Madhya Pradesh and Chhattisgarh states of India [22, 23]. Tikhur is used for preparation of various sweet dishes such as Barfi, Halwa, Jalebi. Barfi (shown in Fig. 17) is usually prepared with Tikhur starch, sugar and water cooked over medium to low flame. When it becomes thick, it is spread onto flat plate to cool down [24]. Jalebi is made by mixing Khoa (condensed milk) and Tikhur. The mixture is put on a specially woven jalebi making cloth, and the batter is then squeezed in to hot ghee on a circular frying pan. Fried jalebi is soaked in sugar syrup [25].

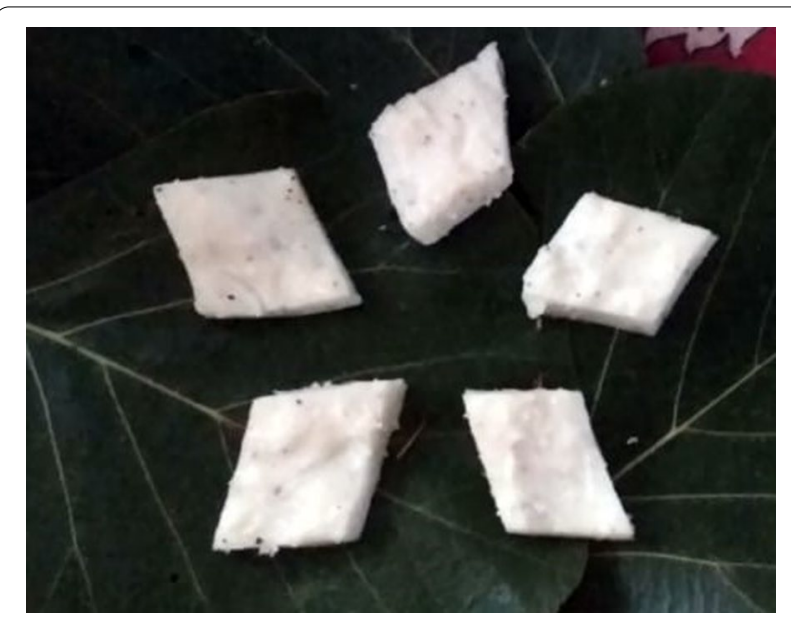

Fig. 17 Tikhur 


\section{Leafy vegetables of Chhattisgarh}

Leafy vegetables are very popular in Chhattisgarh. There are several ways of cooking and consuming these leafy vegetables. The most common is to cut the vegetable into small pieces and cook it on a pan with little oil and adding spices such as mustard, cumin seed, asafoetida. Salt is added as per taste. Many of the leafy vegetables are cooked by mixing with pulses. Cut leaves are mixed with batter of Besan (gram flour) and fried in hot oil. This is commonly called Bhajiya or Pakoda. Cut leaves can also be mixed with rice or wheat flour and water to prepare a dough. Small pieces of this dough are rolled into flat round shapes and are cooked on a heated griddle (Tawa) by smearing oil on it. This dish is popularly known as Paratha in several Indian states. Local vegetables are mixed with flour or are used as stuffing to prepare Parathas. Poori can also be prepared with the same dough. A list of leafy vegetables that are commonly consumed in Chhattisgarh is shown in Table 1.

Tubers and roots of the plants used in Chhattisgarhi food: Chhattisgarh has a large forest cover. Since majority of the state population lives in rural and tribal areas, people have learned to use wild tubers and root of plants. Some of the tubers cultivated are-Amorphophallus paeoniifolius, Colocasia esculenta (L.) Schott, Curcuma amada Roxb, Curcuma angustifolia Roxb, etc. Tubers are commonly boiled in water and cut into small pieces after removing the peel. It is then cooked on a pan with a little oil and spices such as mustard, cumin seed, asafoetida, ginger, coriander. Sweet dishes are also prepared from tubers such as Curcuma angustifolia Roxb and Pueraria tuberosea (Roxb. ex Willd). A list of tubers and root of plants consumed in Chhattisgarh is shown in Table 2

\section{Discussion}

India has a rich and highly diverse food, and its various diets are well closely linked to social identity, religion and other cultural influences [26] as well as local agricultural practices and wide range of food availability [27]. Rice is an important cereal crop that provides food for more than half of the world's population. It is grown in almost all Asian countries, and it is consumed by nearly half of the world's population [28]. Rice is the primary staple of every major Asian meal [29]. Rice is valued as a great emblem of auspiciousness, prosperity, and fertility in Indian culture because of its life-sustaining characteristics. It provides instant and fast energy. Brown and red rice are high in fibre, B vitamins, calcium, zinc, iron, manganese, selenium, magnesium and other nutrients [30]. In the Chhattisgarh state, 4.78 million hectares are cultivated, constituting $35 \%$ of the total geographical area. The state has about 3.7 million hectares under rice cultivation which is mostly rainfed, covering both uplands and shallow lowlands [31].

$44 \%$ of the Chhattisgarh state being forest land, for centuries its rural and tribal communities have played a pivotal role in nurturing and protecting the natural habitat through eco-friendly practices [32]. Cultivated or wildly available leafy vegetables, tubers and root of plants are essential ingredients of food after cereals in this area. These not only enrich the diet of the people but also provide seasonal immunity, cure for the ailments and longevity with their medicinal properties. Because of the presence of functional components such as bodyrecuperating chemicals, antioxidants, dietary fibres and probiotics, Indian traditional foods are also considered as functional foods and these functional molecules help in management of the diseases and support the body's immunity [33, 34].

Health advantages associated with Chhattisgarh's ethnic food are also backed up by traditional medicine and recent medical researches. A number of these evidences about the leafy vegetables (listed in Table 1), tubers and roots (listed in Table 2) are given here further. Leaves of Achyranthes aspera Linn. which is regionally named as Chirchita Bhaji is used as remedy for piles, renal dropsy, pneumonia, cough, kidney stones, skin eruption, snake bite, gonorrhoea and dysentery, etc., within the Ayurveda, Siddha and Unani system of medicine [35, 36]. It is found to possess Gastroprotective [37] Cancer chemopreventive activity [38] and antinociceptive activity [39]. Adhatoda zeylanica Medikus (locally named as Adusa Saag) is a well-known remedy for the respiratory tract complaints [40]. Its leaves contain various alkaloids, including Vasicine, which has broncho dilatory properties, and Vasicine acetate, which has antimycobacterial, antioxidant and anticancer properties [41-43]. Respiratory illnesses are very common during the changing season, and use of Adusa Saag helps the people to regain their health. The decoction made from leaves and shoots of Alternatera sessilis L. (local name-Kurru Bhaji) has antihypertensive [44] and hepatoprotective properties, and in traditional medical system it is used for the treatment of wounds, flatulence, nausea, vomiting, cough, bronchitis, diarrhoea, dysentery and diabetes [45]. Allium cepa L. is one of the oldest cultivated vegetables and extensively used all over the world in all kinds of culture [46]. In Chhattisgarh state, the leaves of the Allium cepa L. are used in multiple ways such as-for making Bhajiya or Pakoda, in the form of salad, as vegetable, chutney, etc. Its leaves are good source of important antioxidants [47]. The leaves of Amaranthus caudatus $L$. (local name-Kedar chua Bhaji) are rich in calcium, iron, zinc, phosphorus and other minerals that can enhance human growth, health and resistance to diseases [48]. 
Table 1 The list of leafy vegetables used in Chhattisgarh State

\begin{tabular}{|c|c|c|c|}
\hline SI.No & Name of Leafy vegetable & Family & Local Name \\
\hline 1 & Achyranthes aspera & Amaranthaceae & Chirchita Bhaji \\
\hline 2 & Adhatoda zeylanica Medikus & Acanthaceae & Adusa Saag \\
\hline 3 & Alternatera sessilis L & Amaranthaceae & Guduru/Kurru Bhaji \\
\hline 4 & Antidesma acidum Retz & Euphorbiaceae & Derango Saag \\
\hline 5 & Allium cepa L & Liliaceae & Gondali/Pyaj Bhaji \\
\hline 6 & Amaranthus caudatus $L$ & Amaranthaceae & Kedar chua Bhaji \\
\hline 7 & Amaranthus gangaticus $L$ & Amaranthaceae & Jadi/Jari Bhaji \\
\hline 8 & Amaranthus spinosus $L$ & Amaranthaceae & Chaulai Kata/Kanta Bhaji \\
\hline 9 & Amaranthus tricolour L & Amaranthaceae & Lal Bhaji \\
\hline 10 & Amaranthus viridis $L$ & Amaranthaceae & Chaulai Bhaji \\
\hline 11 & Bacopa monnieri (L.) Pennell & Scrophulariaceae & Brahmi Saag \\
\hline 12 & Basella rubra L & Basellaceae & Poi Bhaji \\
\hline 13 & Bauhinia purpurea L & Caesalpiniaceae & Koliari Bhaji \\
\hline 14 & Begonia picta Sm & Begoniaceae & Patharchati \\
\hline 15 & Boerhaavia diffusa $L$ & Urticaceae & Patharri Bhaji \\
\hline 16 & Brassica compestris $L$ & Brassicaceae & Sarson Bhaji \\
\hline 17 & Brassica oleracea botrytis $L$ & Brassicaceae & Gobhi Bhaji \\
\hline 18 & Brassica oleracea var. capitata $L$ & Brassicaceae & Bandagobhi Bhaji \\
\hline 19 & Brassica oleracea var.caularpa $L$ & Brassicaceae & Gantha gobhi Bhaji \\
\hline 20 & Butomopsis latifolia Kunth & Butomaceae & Chanti Bhaji \\
\hline 21 & Caesulia axillaries Roxb & Asteraceae & Muchri Bhaji \\
\hline 22 & Capsicum annum L & Solanaceae & Mirchi Bhaji \\
\hline 23 & Carthemnus oxycantha L & Asteraceae & Kusum Bhaji \\
\hline 24 & Cassia mimosoides $\mathrm{L}$ & Caesalpiniaceae & Jirhul Bhaji \\
\hline 25 & Cassia tora L & Caesalpiniaceae & Charota Bhaji \\
\hline 26 & Celosia Argentina & Amaranthaceae & Silyari/Phool Bhaji \\
\hline 27 & Centella asiatica (L.) & Apiaceae & Beng Saag/Muskeni Bhaji \\
\hline 28 & Chenopdium album $L$ & Chenopodiaceae & Bathua Bhaji \\
\hline 29 & Chorchorus olitorius L & Tiliaceae & Chech Bhaji \\
\hline 30 & Cicer arietinum L & Papilionaceae & Chana Bhaji \\
\hline 31 & Cissus qudrangularis & Vitaceae & Hadjod/SingariSaag \\
\hline 32 & Cleome viscosa & Capparidaceae & Hurhuria Bhaji \\
\hline 33 & Coccinia grandis & Cucurbitaceae & Kunduru Bhaji \\
\hline 34 & Colocasia antiquarum Schott & Araceae & Kochai Bhaji \\
\hline 35 & Commelina benghalensis $L$ & Commelinaceae & Kaunaakeny Bhaji \\
\hline 36 & Corchorus acutangulus Lam & Tiliaceae & Masaria Bhaji \\
\hline 37 & Corchorus-Fascicularis & Tiliaceae & Lal Chench Bhaji \\
\hline 38 & Cordia myxa Roxb & Boraginaceae & Bohar Bhaji \\
\hline 39 & Cucumus sativus & Cucurbitaceae & Kakdi Bhaji \\
\hline 40 & Cucurbita maxima Duch & Cucurbitaceae & Kumda Bhaji \\
\hline 41 & Daucus carota & Brassicaceae & Gajar Bhaji \\
\hline 42 & Dolicus lablab & Papilionaceae & Sem Bhaji \\
\hline 43 & Eretia laevis Roxb & Ehretiaceae & Suruh matha Bhaji \\
\hline 44 & Emilia sonchifolia (L.) DC & Asteraceae & Khapraban Bhaji \\
\hline 45 & Euphorbia microphlla Heyne ex Roth & Euphorbiaceae & Lal chimti Bhaji \\
\hline 46 & Ficus religiosa $L$ & Urticaceae & Pipal Bhaji \\
\hline 47 & Hibiscus cannbinus $L$ & Malvaceae & Patawa Bhaji \\
\hline 48 & Hibiscus sabdariffa $L$ & Malvaceae & Amari Bhaji \\
\hline 49 & Ipomoea aquatica Frosk & Convolvulaceae & Karmatta Bhaji \\
\hline
\end{tabular}


Table 1 (continued)

\begin{tabular}{|c|c|c|c|}
\hline SI.No & Name of Leafy vegetable & Family & Local Name \\
\hline 50 & Ipomoea batatas Lam & Convolvulaceae & Kanda Bhaji \\
\hline 51 & Lagenaria vulgaris & Cucurbitaceae & Lauki Bhaji \\
\hline 52 & Lathyrus sativa $L$ & Papilionaceae & Lakhadi/Tivara Bhaji \\
\hline 53 & Lathyrus sp. & Papilionaceae & Jillo Bhaji \\
\hline 54 & Leucas cephalotes Spreng & Lamiaceae & Gumee Bhaji \\
\hline 55 & Marsilea vestita Hook \& Grev & Marsileaceae & Chunchunia/Sunsunia Bhaji \\
\hline 56 & Merremia emarginata Burmf & Convolvulaceae & Muskeny Bhaji \\
\hline 57 & Momordica charantia & Cucurbitaceae & Karela Bhaji \\
\hline 58 & Moringa pterygosperma Lam & Moringaceae & Munga Bhaji \\
\hline 59 & Oxalis corniculata & Oxalidaceae & Amrul/Tinpania Bhaji \\
\hline 60 & Partulaca oleracea L & Partulacaceae & Gol/Kulfa Bhaji \\
\hline 61 & Phaceolus radiatus $L$ & Papilionaceae & Urad Bhaji \\
\hline 62 & Phaseolus vulgaris & Papilionaceae & Barbatti Bhaji \\
\hline 63 & Raphanus sativus $L$ & Brassicaceae & Mooli/Murai Bhaji \\
\hline 64 & Solanum nigrum & Solanaceae & Makoya/Kakamachi Bhaji \\
\hline 65 & Shorea robusta $L$ & Dipterocarpaceae & Hargi Bhaji \\
\hline 66 & Solanum tuberosum $L$ & Solanaceae & Alu Bhaji \\
\hline 67 & Spinacea glabra L & Chenopodiaceae & Khatta Palak Bhaji \\
\hline 68 & Spinacea oleracea L & Chenopodiaceae & Palak Bhaji \\
\hline 69 & Trianthema portulacastrum $L$ & Aizoaceae & Salsa Bhaji \\
\hline 70 & Trigonella foenum graceum L & Papiolionaceae & Methi Bhaji \\
\hline
\end{tabular}

Amaranthus spinosus L. commonly known as Kantabhaji is found in tropical and sub-tropical regions of India [49]. The plant is used as a diuretic, antidiabetic, analgesic, antipyretic, antileprotic and in the treatment of bronchitis and piles in the Ayurveda system of medicine [50]. In traditional medical systems, Bacopa monnieri (L.) Pennell (Brahmi) is a well-known herb as a brain tonic for promoting memory [51] and recommended for the management anxiety, poor cognition and lack of concentration [52]. Basella rubra L., popularly known as Malabar spinach, Indian spinach is widely consumed vegetable in India. Leaves and stem of Basella rubra L. are having mild laxative, demulcent, anticancer, antibacterial, antihyperglycaemic, anti-inflammatory and antiproliferative activity, and its fruits are used as natural colourant in ice cream product [53-57] Boerhavia diffusa Linn. is a commonly used herb in traditional Indian Medicine. A number of studies have demonstrated its immunomodulatory, hepatoprotective, antifibrinolytic, anticancer, antidiabetic, anti-inflammation, antiviral, antimicrobial and diuretic effects [58-62]. In Ayurveda, fresh juice of Centella asiatica (L.) is used as Medhya (cognitive enhancer) drug [63]. It is having wide range of biological activities such as neuroprotective [64], anticonvulsant [65], antinociceptive and anti-inflammatory effects [66], immunostimulant [67], antidepressant [68], antigastric ulcer [69], wound healing [70].
Roots and tubers are important staples for over 1000 million people in the developing world [71]. Traditionally Amorphophallus paeoniifolius is useful in arthralgia, elephantiasis, tumoUrs, inflammations, haemorrhoids, haemorrhages, vomiting, cough, bronchitis, asthma, anorexia, dyspepsia, flatulence, colic, constipation, helminthiasis hepatopathy, splenomegaly, amenorrhoea, dysmenorrhoea, seminal weakness, fatigue, anaemia and general debility $[72,73]$. In India, among the tribes, its tuber is most commonly used for the management of haemorrhoids [74]. In a study, Amorphophallus paeoniifolius has shown an anticolitic effect through its anti-inflammatory and antioxidant activity in colon of Wistar rats [75]. Asparagus racemosus is used as a general health promoter in Ayurveda. It is a main drug for improving female reproductive health, and so only it is also known as the 'Queen of herbs' [76]. Various animal and clinical studies have demonstrated that Asparagus racemosus is having antileishmanial [77], antitumoUr [78], immunomodulatory [79], antidepressant [80], antihyperglycaemic [81] and anti-infertility [82] activities. Costus speciosus (Koenig) Sm. is used as vegetables in many Indian states and also widely used in traditional medicines in the management of several ill health conditions such as jaundice, diabetes, pneumonia, rheumatism and skin diseases. A number of studies reported that it is having anticancer [82], anti-inflammatory [83], 
Table 2 The list of Tubers and roots of the plants used in Chhattisgarhi food

\begin{tabular}{|c|c|c|c|}
\hline SI.No & Name of Tubers and roots & Family & Local Name \\
\hline 1 & Abelmoschus moschatus medic & Malvaceae & Janglibhindi \\
\hline 2 & Amorphophallus paeoniifolius & Araceae & Sirdikand, Surankand, Jimikand \\
\hline 3 & Asparagus racemosus & Liliaceae & Satawar, Satmuli \\
\hline 4 & Chlorophytum borivilianum & Liliaceae & Korkota Kanda \\
\hline 5 & Colocasia esculenta (L.) Schott & Araceae & Kochai, Arvi, Ghuiyan \\
\hline 6 & Costus speciosus (Koenig) Sm & Costaceae & Kewkanda \\
\hline 7 & Curculigo orchioides Gaertn & Amaryllidaceae & Kali musli, Musali kand \\
\hline 8 & Curcuma amada Roxb & Zingiberaceae & Amahaldi \\
\hline 9 & Curcuma angustifolia Roxb & Zingiberaceae & Tikhur, Batri \\
\hline 10 & Curcuma caesia Roxb & Zingiberaceae & Kalihaldi \\
\hline 11 & Dendrocalamus strictus (Roxb.) & Poaceae & Dongri bans \\
\hline 12 & Dioscorea alata (L.) & Dioscoreaceae & Ratalu, Nagarkand, Uskakand \\
\hline 13 & Dioscorea belophylla Voigt ex Haines & Dioscoreaceae & Genthi Kanda \\
\hline 14 & Dioscorea bulbifera (L.) & Dioscoreaceae & Damgkanda, Lathikanda \\
\hline 15 & Dioscorea hispida & Dioscoreaceae & Kuliakand \\
\hline 16 & Dioscorea oppositifolia & Dioscoreaceae & Tagariyakand \\
\hline 17 & Dioscorea pentaphylla (L.) & Dioscoreaceae & Suwarkanda, Barhakanda \\
\hline 18 & Dioscorea bulbifera var. pulchella & Dioscoreaceae & Pitakand, Karukanda \\
\hline 19 & Dioscorea triphilla L & Dioscoreaceae & Lakra kanda \\
\hline 20 & Hibiscus rugosus & Malvaceae & Dhokrakanda \\
\hline 21 & Ipomoea batatas (L.) Lamk & Convolvulaceae & Mitha aalu, Shakarkand \\
\hline 22 & Leea macrophylla (Roxb. ex Hornem) & Leeaceae & Dhotelakand \\
\hline 23 & Pueraria tuberosea (Roxb. ex Willd) & Fabaceae & Patal kumda, Bidari kand \\
\hline 24 & Scirpus grossus (L.f.) & Cyperaceae & Kaseru Kand \\
\hline 25 & Urginea indica (Roxb.) Kunth & Liliaceae & Bailaagodri, Jangali-piyaz \\
\hline
\end{tabular}

antitubercular [84], antihyperglycaemic [85], antimicrobial [86], hepatoprotective [87], antioxidant and antihyperlipidemic [88] activities. Curculigo orchioides Gaertn (Kali Musali in Hindi) is well known for its immunomodulatory and rejuvenating effects [89]. In Ayurvedic system, it is specially used as a potent adaptogen and aphrodisiac medicine [90]. The medicinal plant has demonstrated a wide spectrum pharmacological activity, including antistress [91], immunostimulatory [92], hepatoprotective [93], antirheumatic [94], antihistaminic [95] and antiasthmatic [96], anti-inflammatory [97, 98], analgesic [99], antioxidant and anticancerous [100] activity. The rhizome of Curcuma amada Roxb, commonly known as mango ginger due to its characteristic raw mango aroma, is used as an appetizer, antipyretic, aphrodisiac and laxative in Ayurveda system of medicine [101]. It is reported to have antimicrobial, antioxidant, cytotoxicity and platelet aggregation inhibitory activity [102], CNS depressant and analgesic activity [103], antifungal [104], antitubercular activity [105], anticancer [106] and cytotoxic activity [107]. Ipomoea batatas (L.) Lamk is considered to be a major food crop worldwide, and it is delicious, sweet taste, nutritious vegetable with high starch content $[108,109]$. It is having anti-inflammatory and anticancer properties [110], antimutagenic [111], antidiabetic activity [112], hepatoprotective [111], antioxidant and probiotic activities [113]. Pueraria tuberosea (Roxb. ex Willd) is widely used in the treatment of fever, menorrhagia, skin diseases, wounds, bronchial asthma and jaundice in Ayurveda [114]. It is reported to have anti-inflammatory [115], hypolipidemic [116], antifertility [117], antidiabetic [118], nephroprotective [119], anticancer [120], anticonvulsant [121], antistress [122] cardioprotective [123] antioxidant and antiapoptotic effect [124].

Although leafy vegetables, tubers and roots are having vital roles to fulfil dietary need of the Indian tribes, still its nutritional value and medicinal uses are not very well explored [125]. Even without having proper access to the modern medical facilities, Chhattisgarh tribes are able to manage several health issues with their knowledge of using natural plant resources. Many tribal communities live in Chhattisgarh state such as Gond, Halba, Dhurvaa, Muria, Abujhmadia, Kawar, Binjwar who are having good knowledge about the utility of the locally available medicinal flora $[126,127]$. In a recent publication, for the 
treatment of jaundice, approximately 55 medicinal plants were documented which are used by rural and tribal people of different area of Chhattisgarh [128]. Such information can be helpful to provide better and cost-effective solution for the several challenging health issues. Chhattisgarh food culture is not just about satisfying the hunger but to take care the complete dietary and health need of the people.

\section{Conclusion}

The 'Rice Bowl' of Central India, Chhattisgarh, has a rich ethnic food culture. Rice is the principal crop and diet of the people here. The large forest cover of the region is a great storage bank of several leaves, edible wild tubers and roots which serve as a supplementary diet of the people and gives a unique flavour and medicinal value to the food. We see globally that many of the traditional dietary ingredients are slowly going out of the food plate and our diet is limited to only a few varieties of ingredients. In spite of this, Chhattisgarh is maintaining its traditional food practices remarkably well. This also indicates that we should not depend on food from elsewhere and learn to utilize the available natural resources. Nature has several ways to protect us, but we have to learn to protect nature and utilize its resources judiciously. Protecting, reviving and following the traditional food patterns can be one of the easiest and the best ways to create a healthy society.

\section{Future prospects of ethnic food culture}

The concept of ethnic food culture does not just refer to food types, cooking methods, and nutritional and medicinal values, but also to people's cultural heritage, religious practices and way of life. Historically, traditional foods carry knowledge transferred across generations for making them wholesome for consumption. A number of modifications may have been made before they were included in the food culture. Taking the popular South Indian food item Dosa as an example, in Chhattisgarh (Central India), a similar food item called Cheela is prepared without fermentation. It may have to do with the climatic conditions in south India, where fermentation occurs easily due to a warm and humid climate of various regions. These modifications can be seen in almost every traditional food culture. Traditional foods of the different islands reflect the island's ecology and biodiversity [129]. Throughout the world, food cultures face inevitability challenges caused by urbanization and social changes [130]. Unplanned urbanization has separated a large part of the world's population from the direct production of foods, which has produced changes in eating behaviour [131]. People who eat according to the rules of a traditional food culture are healthier than those who are eating processed-food-based modern diet so-called fast food [132]. It is quite surprising that even without much medical facilities, people from rural areas are able to maintain their health across different situations of life. Food culture has a prominent role in this. In Chhattisgarh's food culture, it is clearly evident and available research data that also support the use of various plants and tubers for prevention and management of illnesses. There is a need to scientifically understand the principles behind the traditional food culture. Adopting to a new kind of food item which is not traditionally used must be based on the principles which are followed in the particular food culture. Violating the rules and blindly adopting to a new kind of food pattern may have adverse effects on the health of the population and also damaging for the whole traditional system. Traditional food culture can even enrich the present health science by knowing the use of various herbs and food modifications during ill-health.

\begin{abstract}
Acknowledgements
I am extremely thankful to Dr. Heerachand Patel and Dr. Vivek Dubey, lecturer, Govt. Ayurveda College, Bilaspur, Mr. Sanjay Pandey, lecturer, Govt. High School, Village-Mehana, Bemetara Dist, Mrs. Pramila Shrivastava and Mr. Awadhesh Shrivastava, Retd School teacher, Khaparganj, Bilaspur Dist., Rekha Shrivastava, women and child development officer, Malkharoda, Janjgir Dist, and Mrs. Pratima Pandey, lecturer, Govt. Tribal Higher Secondary School, Village-Lanjoda, Kondagaon Dist., for their help in collecting information and pictures of Chhattisgarh traditional foods. Special thanks to Dr. Maanasi Menon, Associate Professor, Amrita School of Ayurveda, for helping in proof reading of the article. I am also very much thankful to the expert reviewers for their insightful suggestions and the whole team of Journal of ethnic Foods for their support in each step of this publication.
\end{abstract}

\section{Authors' contributions}

AS* is the sole author of the article. The author's schooling and working place is Chhattisgarh state, and this has helped to collect the information about the traditional food culture of Chhattisgarh state. The author read and approved the final manuscript.

Funding

Nil.

Availability of data and materials

Not applicable.

\section{Declarations}

Competing interests

The author declares that he has no competing interest.

Received: 13 May 2021 Accepted: 30 September 2021

Published online: 18 October 2021

\footnotetext{
References

1. Directorate Agriculture, Chhattisgarh Raipur. http://agriportal.cg.nic.in/ agridept/AgriEn/Default.aspx. Accessed 6 June 2020.

2. Kearney J. Food consumption trends and drivers. Philos Trans R Soc Lond B Biol Sci. 2010;365(1554):2793-807. https://doi.org/10.1098/rstb. 2010.0149.

3. Diet, Nutrition And The Prevention of Chronic Diseases, Joint WHO/FAO Expert Consultation on Diet, Nutrition and the Prevention of Chronic
} 
Diseases (2002: Geneva, Switzerland) (WHO technical report series; 916), ISBN 924120916 X. http://whqlibdoc.who.int/trs/who_trs_916. pdf. Accessed 6 June 2020.

4. Investment Climate in Chhattisgarh, Demographic profile. https://www. ibef.org/download/IBEF_CHHATISGARH_260508.pdf. Accessed 6 June 2020

5. Chauhan D, Shrivastava AK, Patra S. Diversity of leafy vegetables used by tribal peoples of Chhattisgarh, India. Int J Curr Microbiol App Sci. 2014:3(4):611-22.

6. Ajay B, Sharad N, Deo S. Wild edible tuber and root plants available in Bastar region of Chhattisgarh. Int J For Crop Improv. 2014;5(2):85-9.

7. Misra S, Maikhuri RK, Kala CP, Rao KS, Saxena KG. Wild leafy vegetables: a study of their subsistence dietetic support to the inhabitants of Nanda Devi Biosphere Reserve. India J Ethnobiol Ethnomed. 2008:4:15.

8. Bai Y, Lindhout P. Domestication and breeding of tomatoes: what have we gained and what can we gain in the future? Ann Bot. 2007;100(5):1085-94. https://doi.org/10.1093/aob/mcm150.

9. Bergougnoux $\mathrm{V}$. The history of tomato: from domestication to biopharming. Biotechnol Adv. 2014;32(1):170-89. https://doi.org/10.1016/j. biotechadv.2013.11.003.

10. Mehta R. History of tomato (Poor Man's Apple). IOSR J Hum Soc Sci (IOSR-JHSS). 2017;22(8):31-4

11. A Contract Farming Agreement for Potato Seed Multiplication in India. http://www.fao.org/in-action/contract-farming/training/module-3/ case-study-potato-in-india/fr/. Accessed 12 June 2020

12. Swarup V, Chatterjee SS. Origin and genetic improvement of Indian cauliflower. Econ Bot. 1972;26(4):381-93.

13. $1 / 3 \mathrm{rd}$ of what we eat today is foreign. https://timesofindia.indiatimes. com/home/sunday-times/deep-focus/1/3rd-of-what-we-eat-today-isforeign/articleshow/52919858.cms. Accessed 12 June 2020.

14. Sachdeva S, Sachdev TR, Sachdeva R. Increasing fruit and vegetable consumption: challenges and opportunities. Indian J Commun Med. 2013;38(4):192-7. https://doi.org/10.4103/0970-0218.120146.

15. Fresh Fruits \& Vegetables. http://apeda.gov.in/apedawebsite/six_head_ product/FFV.htm. Accessed 12 June 2020

16. Meenakshi JV. Trends and patterns in the triple burden of malnutrition in India. Agric Econ. 2016;47(S1):115-34.

17. Singh A, Singh RK, Sureja AK. Cultural significance and diversities of ethnic foods of Northeast India. Indian J Tradit Knowl. 2007;6(1):79-94.

18. Shukla A, Shukla A. Changing food trend and associated health risks. Int J Food Nutr Sci. 2020;9:39-41.

19. Risk Factors Collaborators. Global, regional, and national comparative risk assessment of 79 behavioural, environmental and occupational, and metabolic risks or clusters of risks in 188 countries, 1990-2013: a systematic analysis for the Global Burden of Disease Study 2013. Lancet (London, England). 2013;386(10010):2287-323. https://doi.org/10.1016/ S0140-6736(15)00128-2.

20. Sarkar P, Lohith KDH, Dhumal C, Panigrahi SS, Choudhary R. Traditional and ayurvedic foods of Indian origin. J Ethn Foods. 2015;2(3):97-109. https://doi.org/10.1016/j.jef.2015.08.003.

21. Dhanya S, Ramesh NV, Mishra A. Traditional methods of food habits and dietary preparations in ayurveda—-the Indian system of medicine. J Ethn Food. 2019. https://doi.org/10.1186/s42779-019-0016-4.

22. Ray S, Sheikh M, Mishra S. Ethnomedicinal plants used by tribals of East Nimar region. Madhya Pradesh Indian J Pharm Sci. 2011;45(5):216-20.

23. Deo S, Patel S, Sahu MK, Mukherjee SC. Study on standardization of starch extraction time from rhizomes of tikhur (Curcuma angustifolia Roxb.). Int J Agric Eng. 2014;7(2):436-41.

24. Chandel N, Ram DS, Paikra MS, Banjare C, Patel N. Study on preparation procedure and standardization of recipe of Tikhur Burfi blended with cashew nut kernel. Int J Curr Microbiol App Sci. 2019;8(04):3040-6.

25. Kumari R, Shrivastava SL, Mishra HN. Optimization of khoa and Tikhur mix for preparation of Khoa-Jalebi sweet. Open Access Sci Rep. 2012:1:469. https://doi.org/10.4172/scientificreports.469.

26. Vecchio MG, Paramesh EC, Paramesh H, Loganes C, Ballali S, Gafare CE, Verduci E, Gulati A. Types of food and nutrient intake in India: a literature review. Indian J Pediatr. 2014;81(Suppl 1):17-22. https://doi.org/10. 1007/s12098-014-1465-9.

27. Subramanyam M, Kawachi I, Berkman L, Subramanian S. Socioeconomic inequalities in childhood undernutrition in India: analyzing trends between 1992 and 2005. PLoS ONE. 2010:5:e11392.
28. Pathak H, Tripathi R, Jambhulkar NN, Bisen JP, Panda BB. Eco-regional rice farming for enhancing productivity, profitability and sustainability. NRRI Research Bulletin No. 22, ICAR-National Rice Research Institute, Cuttack 753006, Odisha, India. (2020), pp 28. https://icar-nrri.in/wpcontent/uploads/2020/05/NRRI-Research-Bulletin-22.pdf. Accessed 06 July 2021.

29. Chi J. Consuming rice, branding the nation. Contexts. 2014;13(3):505. https://doi.org/10.1177/1536504214545761.

30. Rathna Priya T, Eliazer Nelson ARL, Ravichandran K, et al. Nutritional and functional properties of coloured rice varieties of South India: a review. J Ethn Food. 2019;6:11. https://doi.org/10.1186/ s42779-019-0017-3.

31. Chhattisgarh. https://icar.org.in/files/state-specific/chapter/41.htm. Accessed 06 July 2021.

32. Chhattisgarh. https://www.incredibleindia.org/content/incredible india/en/destinations/states/chhattisgarh.html. Accessed 9 June 2020.

33. Kone ML, Samayamanthula DR. Significance of conventional Indian foods acting as immune boosters to overcome COVID-19. Environ Resil Transf Times COVID-19. 2021. https://doi.org/10.1016/B978-0-32385512-9.00034-6.

34. Barua CC, Talukdar A, Begum SA, Borah P, Lahkar M. Anxiolytic activity of methanol leaf extract of Achyranthes aspera Linn in mice using experimental models of anxiety. Indian J Pharmacol. 2012;44(1):63-7. https:// doi.org/10.4103/0253-7613.91869.

35. Bhosale UA, Yegnanarayan R, Pophale P, Somani R. Effect of aqueous extracts of Achyranthes aspera Linn. on experimental animal model for inflammation. Anc Sci Life. 2012;31(4):202-6. https://doi.org/10.4103/ 0257-7941.107362.

36. Das AK, Bigoniya P, Verma NK, Rana AC. Gastroprotective effect of Achyranthes aspera Linn. leaf on rats. Asian Pac J Trop Med. 2012;5(3):197201. https://doi.org/10.1016/S1995-7645(12)60024-8.

37. Chakraborty A, Brantner A, Mukainaka T, Nobukuni Y, Kuchide M, Konoshima T, Tokuda H, Nishino H. Cancer chemopreventive activity of Achyranthes aspera leaves on Epstein-Barr virus activation and twostage mouse skin carcinogenesis. Cancer Lett. 2002;177(1):1-5. https:// doi.org/10.1016/s0304-3835(01)00766-2.

38. Barua CC, Talukdar A, Begum SA, Lahon LC, Sarma DK, Pathak DC, Borah P. Antinociceptive activity of methanolic extract of leaves of Achyranthes aspera Linn. (Amaranthaceae) in animal models of nociception. Indian J Exp Biol. 2010;48(8):817-21.

39. Claeson UP, Malmfors T, Wikman G, Bruhn JG. Adhatoda vasica: a critical review of ethnopharmacological and toxicological data. J Ethnopharmacol. 2000;72(1-2):1-20. https://doi.org/10.1016/s0378-8741(00) 00225-7.

40. Gupta OP, Sharma ML, Ghatak BJR, Atal CK. Potent uterine activity of alkaloid vasicine. Indian J Med Res. 1977:66(5):865-71.

41. Ignacimuthu S, Shanmugam N. Antimycobacterial activity of two natural alkaloids, vasicine acetate and 2-acetyl benzylamine, isolated from Indian shrub Adhatoda vasica Ness. leaves. J Biosci. 2010;35(4):565-70. https://doi.org/10.1007/s12038-010-0065-8.

42. Duraipandiyan V, Al-Dhabi NA, Balachandran C, Ignacimuthu S, Sankar C, Balakrishna K. Antimicrobial, antioxidant, and cytotoxic properties of vasicine acetate synthesized from vasicine isolated from Adhatoda vasica L. Biomed Res Int. 2015;2015: 727304. https://doi.org/10.1155/ 2015/727304

43. Acharya E, Pokherl B. Ethno-medicinal plants used by Bantar of Bhaudaha Morang. Nepal Nat. 2006;4:96-103.

44. Bhuyan B, Baishya K, Rajak P. Effects of Alternanthera sessilis on liver function in carbon tetra chloride induced hepatotoxicity in wister rat model. Indian J Clin Biochem. 2018;33(2):190-5. https://doi.org/10. 1007/s12291-017-0666-1.

45. Sidhu JS, Ali M, Al-Rashdan A, Ahmed N. Onion (Allium cepa L.) is potentially a good source of important antioxidants. J Food Sci Technol. 2019;56(4):1811-9. https://doi.org/10.1007/s13197-019-03625-9.

46. Lee J, Hwang S, Ha I, et al. Comparison of bulb and leaf quality, and antioxidant compounds of intermediate-day onion from organic and conventional systems. Hortic Environ Biotechnol. 2015;56:427-36. https://doi.org/10.1007/s13580-015-1036-7.

47. Enujiugha VN, Oluwole TF, Talab JY, Okunlola Al. Selected bioactive components in fluted pumpkin (Telfairia occidentalis) and amaranth 
(Amaranthus caudatus) leaves. J Exp Agric Int. 2014;4(9):996-1006. https://doi.org/10.9734/AJEA/2014/1082.

48. Girija K, Lakshman K, Udaya C, Sabhya SG, Divya T. Anti-diabetic and anti-cholesterolemic activity of methanol extracts of three species of Amaranthus. Asian Pac J Trop Biomed. 2011;1(2):133-8. https://doi.org/ 10.1016/S2221-1691(11)60011-7.

49. Council of Scientific and Industrial Research. The wealth of India: publications and information directorate. New Delhi: Council of Scientific and Industrial Research; 1988. pp. 219-221.

50. Gubbannavar JS, Chandola HM, Harisha CR, Khanpara K, Shukla VJ. A comparative pharmacognostical and preliminary physico-chemical analysis of stem and leaf of Bacopa monnieri (L.) Pennel and Bacopa floribunda (R.BR.) Wettst. Ayu. 2013;34(1):95-102. https://doi.org/10. 4103/0974-8520.115441.

51. Russo A, Borrelli F. Bacopa monniera, a reputed nootropic plant: an overview. Phytomed Int J Phytother Phytopharmacol. 2005;12:305-17.

52. Kumar SS, Manoj P, Giridhar P. A method for red-violet pigments extraction from fruits of Malabar spinach (Basella rubra) with enhanced antioxidant potential under fermentation. J Food Sci Technol. 2015;52:3037-43. https://doi.org/10.1007/s13197-014-1335-5.

53. Kumar SS, Manoj P, Shetty NP, Prakash M, Giridhar P. Characterization of major betalain pigments -gomphrenin, betanin and isobetanin from Basella rubra $L$. fruit and evaluation of efficacy as a natural colourant in product (ice cream) development. J Food Sci Technol. 2015;52(8):49945002. https://doi.org/10.1007/s13197-014-1527-z.

54. Priya K, Gupta A, Mahajan S, Agnihotri RK, Sharma R. Evaluation of antimicrobial properties of Basella rubra methanolic extracts on selected microorganisms. Int J Pharma Sci Drug Res. 2015;6:334-6.

55. Kilari BP, Kotakadi VS, Penchalaneni J. Anti-proliferative and apoptotic effects of Basella rubra (L.) against 1, 2-dimethyl hydrazine-induced colon carcinogenesis in rats. Asian Pac J Cancer Prev. 2016;17(1):73-80. https://doi.org/10.7314/apjcp.2016.17.1.73.

56. Kumar BR, Anupam A, Manchikanti P, Rameshbabu AP, Dasqupta S, Dhara S. Identification and characterization of bioactive phenolic constituents, anti-proliferative, and anti-angiogenic activity of stem extracts of Basella alba and rubra. J Food Sci Technol. 2018;55(5):1675-84. https://doi.org/10.1007/s13197-018-3079-0.

57. Chandan BK, Sharma AK, Anand KK. Boerhaavia diffusa: a study of its hepatoprotective activity. J Ethnopharmacol. 1991;31 (3):299-307. https://doi.org/10.1016/0378-8741(91)90015-6 (PMID: 2056758).

58. Pari L, Amarnath SM. Antidiabetic effect of Boerhavia diffusa: effect on serum and tissue lipids in experimental diabetes. J Med Food. 2004;7(4):472-6

59. Srivastava R, Saluja D, Dwarakanath BS, Chopra M. Inhibition of human cervical cancer cell growth by ethanolic extract of Boerhaavia diffusa Linn. (Punarnava) root. Evid Based Complement Alternat Med. 2011;2011:427031. https://doi.org/10.1093/ecam/nep223.

60. Mishra S, Aeri V, Gaur PK, Jachak SM. Phytochemical, therapeutic, and ethnopharmacological overview for a traditionally important herb: Boerhavia diffusa Linn. Biomed Res Int. 2014;2014: 808302. https://doi. org/10.1155/2014/808302

61. Alam P, Shahzad N, Gupta AK, et al. Anti-diabetic effect of Boerhavia diffusa $L$. root extract via free radical scavenging and antioxidant mechanism. Toxicol Environ Health Sci. 2018;10:220-7. https://doi.org/ 10.1007/s13530-018-0367-z.

62. Acharya YT, editor. Caraka Samhita with Chakrapani's Ayurveda Deepika Teeka. Varanasi: Choukhamba Samskrita Samsthana; 1994. Agnivesha; p. 385.

63. Orhan IE. Centella asiatica (L.) urban: from traditional medicine to modern medicine with neuroprotective potential. Evid Based Complement Alternat Med. 2012;2012:946259. https://doi.org/10.1155/2012/946259.

64. Vattanajun A, Watanabe $H$, Tantisira MH, Tantisira B. Isobolographically additive anticonvulsant activity between Centella asiatica's ethyl acetate fraction and some antiepileptic drugs. J Med Assoc Thai. 2005:88(supplement 3):S131-140.

65. Somchit MN, Sulaiman MR, Zuraini A, Samsuddin LN, Somchit N, Israf DA, et al. Antinociceptive and antiinflammatory effects of Centella asiatica. Indian J Pharmacol. 2004;36:377-80

66. Wang XS, Dong Q, Zuo JP, Fang JN. Structure and potential immunological activity of a pectin from Centella asiatica (L.) Urban. Carbohydr Res. 2003;338(22):2393-402.
67. Chen Y, Han T, Qin L, Rui Y, Zheng H. Effect of total triterpenes from Centella asiatica on the depression behavior and concentration of amino acid in forced swimming mice. Zhong Yao Cai. 2003;26(12):870-3.

68. Cheng CL, Guo JS, Luk J, Koo MW. The healing effects of Centella extract and asiaticoside on acetic acid induced gastric ulcers in rats. Life Sci. 2004;74(18):2237-49. https://doi.org/10.1016/j.lfs.2003.09.055.

69. Suguna L, Sivakumar P, Chandrakasan G. Effects of Centella asiatica extract on dermal wound healing in rats. Indian J Exp Biol. 1996;34(12):1208-11.

70. The Sources of Food. http://www.fao.org/3/u8480e/u8480e07.htm. Accessed 06 July 2021

71. Nair RV. Indian medicinal plants 3. Madras: Orient Longman; 1993. p. 118-22.

72. Dey YN, Ota S, Srikanth N, Jamal M, Wanjari M. A phytopharmacological review on an important medicinal plant-Amorphophallus paeoniifolius. Ayu. 2012;33(1):27-32. https://doi.org/10.4103/0974-8520.100303.

73. Dey YN, Wanjari MM, Kumar D, Lomash V, Jadhav AD. Curative effect of Amorphophallus paeoniifolius tuber on experimental hemorrhoids in rats. J Ethnopharmacol. 2016;4(192):183-91. https://doi.org/10.1016/j. jep.2016.07.042

74. Dey YN, Sharma G, Wanjari MM, Kumar D, Lomash V, Jadhav AD. Beneficial effect of Amorphophallus paeoniifolius tuber on experimental ulcerative colitis in rats. Pharm Biol. 2017;55(1):53-62. https://doi.org/10 1080/13880209.2016.1226904.

75. Alok S, Jain SK, Verma A, Kumar M, Mahor A, Sabharwal M. Plant profile, phytochemistry and pharmacology of Asparagus racemosus (Shatavari): a review. Asian Pac J Trop Dis. 2013;3(3):242-51. https://doi.org/10. 1016/52222-1808(13)60049-3.

76. Sachdeva H, Sehgal R, Kaur S. Asparagus racemosus ameliorates cisplatin induced toxicities and augments its antileishmanial activity by immunomodulation in vivo. Parasitol Int. 2014;63(1):21-30. https://doi.org/10 1016/j.parint.2013.09.016.

77. Shao Y, Chin CK, Ho CT, Ma W, Garrison SA, Huang MT. Anti-tumor activity of the crude saponins obtained from asparagus. Cancer Lett. 1996;104(1):31-6. https://doi.org/10.1016/0304-3835(96)04233-4.

78. Gautam M, Saha S, Bani S, Kaul A, Mishra S, Patil D, Satti NK, Suri KA, Gairola S, Suresh K, Jadhav S, Qazi GN, Patwardhan B. Immunomodulatory activity of Asparagus racemosus on systemic Th1/Th2 immunity: implications for immunoadjuvant potential. J Ethnopharmacol. 2009;121(2):241-7. https://doi.org/10.1016/j.jep.2008.10.028.

79. Singh GK, Garabadu D, Muruganandam AV, Joshi VK, Krishnamurthy S. Antidepressant activity of Asparagus racemosus in rodent models. Pharmacol Biochem Behav. 2009;91(3):283-90. https://doi.org/10.1016/j. pbb.2008.07.010.

80. Hannan JM, Ali L, Khaleque J, Akhter M, Flatt PR, Abdel-Wahab YH. Antihyperglycaemic activity of Asparagus racemosus roots is partly mediated by inhibition of carbohydrate digestion and absorption, and enhancement of cellular insulin action. Br J Nutr. 2012;107(9):1316-23. https://doi.org/10.1017/S0007114511004284.

81. Pandey AK, Gupta A, Tiwari M, Prasad S, Pandey AN, Yadav PK, Sharma A Sahu K, Asrafuzzaman S, Vengayil DT, Shrivastav TG, Chaube SK. Impact of stress on female reproductive health disorders: possible beneficial effects of shatavari (Asparagus racemosus). Biomed Pharmacother. 2018;103:46-9. https://doi.org/10.1016/j.biopha.2018.04.003.

82. Selim S, Al Jaoni S. Anticancer and apoptotic effects on cell proliferation of diosgenin isolated from Costus speciosus (Koen.) Sm. BMC Complement Altern Med. 2015;15:301. https://doi.org/10.1186/ s12906-015-0836-8.

83. Selim S, Al Jaouni S. Anti-inflammatory, antioxidant and antiangiogenic activities of diosgenin isolated from traditional medicinal plant, Costus speciosus (Koen ex.Retz.) Sm. Nat Prod Res. 2016;30(16):1830-3. https:// doi.org/10.1080/14786419.2015.1065493.

84. Mohamad S, Ismail NN, Parumasivam T, Ibrahim P, Osman H, Wahab AH. Antituberculosis activity, phytochemical identification of Costus speciosus (J. Koenig) Sm., Cymbopogon citratus (DC. Ex Nees) Stapf., and Tabernaemontana coronaria (L.) Willd. and their effects on the growth kinetics and cellular integrity of Mycobacterium tuberculosis H37Rv. BMC Complement Altern Med. 2018;18(1):5. https://doi.org/10.1186/ s12906-017-2077-5. 
85. Ali HA, Almaghrabi OA, Afifi ME. Molecular mechanisms of anti-hyperglycemic effects of Costus speciosus extract in streptozotocin-induced diabetic rats. Saudi Med J. 2014;35(12):1501-6.

86. Duraipandiyan V, Al-Harbi NA, Ignacimuthu S, Muthukumar C. Antimicrobial activity of sesquiterpene lactones isolated from traditional medicinal plant, Costus speciosus (Koen ex.Retz.) Sm. BMC Complement Altern Med. 2012;12:13. https://doi.org/10.1186/1472-6882-12-13.

87. Verma N, Khosa RL. Evaluation of protective effects of ethanolic extract of Costus speciosus (Koenig) Sm. Rhizomes on carbon tetrachloride induced hepatotoxicity in rats. Natl Prod Radiance. 2009;8:123-6.

88. Shediwah FMH, Naji KM, Gumaih HS, Alhadi FA, Al-Hammami AL, D'Souza MR. Antioxidant and antihyperlipidemic activity of Costus speciosus against atherogenic diet-induced hyperlipidemia in rabbits. J Integr Med. 2019;17(3):181-91. https://doi.org/10.1016/j.joim.2019.02. 002.

89. Murali VP, Kuttan G. Curculigo orchioides gaertn effectively ameliorates the uro- and nephrotoxicities induced by cyclophosphamide administration in experimental animals. Integr Cancer Ther. 2016;15(2):205-15. https://doi.org/10.1177/1534735415607319.

90. Chauhan NS, Sharma V, Thakur M, Dixit VK. Curculigo orchioides: the black gold with numerous health benefits. Zhong Xi Yi Jie He Xue Bao. 2010;8(7):613-23. https://doi.org/10.3736/jcim20100703.

91. Chauhan NS, Shah K, Gupta PK. Studies on antistress activity of Curculigo orchioides gaertn. Biomed Biotechnol Res J. 2021:5:145-8.

92. Lakshmi V, Pandey K, Puri A, Saxena RP, Saxena KC. Immunostimulant principles from Curculigo orchioides. J Ethanopharmacol. 2003;89(2-3):181-4

93. Babu G, Shalima NK, Divya TA, Divya T. Evaluation of hepatoprotective activity of rhizomes of Curculigo orchioides gaertn. Res J Pharm Technol. 2013;6(10):1127-30.

94. Ding H, Gao G, Zhang L, Shen G, Sun W, Gu Z, Fan W. The protective effects of curculigoside $A$ on adjuvant-induced arthritis by inhibiting NF-KB/NLRP3 activation in rats. Int Immunopharmacol. 2016;30:43-9.

95. Venkatesh P, Mukherjee PK, Kumar SN, Nema NK, Bandyopadhyay A, Fukui $\mathrm{H}$, Mizuguchi H. Mast cell stabilization and antihistaminic potentials of Curculigo orchioides rhizomes. J Ethnopharmacol. 2009;126(3):434-6.

96. Pandit P, Singh A, Bafna AR, Kadam PV, Patil MJ. Evaluation of antiasthmatic activity of Curculigo orchioides Gaertn rhizomes. Indian J Pharm Sci. 2008;70(4):440-4.

97. Agrahari AK, Panda SK, Meher A, Pradhan AR. Studies on the antiinflammatory properties of Curculigo orchioides Gaertn. Root Tubers Int J Pharm Sci Res. 2010;1(8):139-43.

98. Dode PA, Wani NS, Deshmukh TA, Patil VR. Anti inflammatory activity of hydrogel formulations of Curculigo orchioides (Gaertn) rhizomes. Pharmacologyonline. 2009;2:1367-81.

99. Madhavan V, Joshi R, Murali A, Yoganarasimhan SN. Evaluation of analgesic activity of root tuber of Curculigo orchioides Gaertn. Indian J Pharm Educ Res. 2007;41(4):365-8.

100. Hejazi II, Khanam R, Mehdi SH, Bhat AR, Rizvi MMA, Thakur SC, Athar F. Antioxidative and anti-proliferative potential of Curculigo orchioides Gaertn in oxidative stress induced cytotoxicity: in vitro, ex vivo and in silico studies. Food Chem Toxicol. 2018;115:244-59. https://doi.org/10. 1016/j.fct.2018.03.013.

101. Policegoudra RS, Aradhya SM, Singh L. Mango ginger (Curcuma amada Roxb.) - a promising spice for phytochemicals and biological activities. J Biosci. 2011;36(4):739-48. https://doi.org/10.1007/s12038-011-9106-1.

102. Policegoudra RS, Rehna K, Rao LJ, Aradhya SM. Antimicrobial, antioxidant, cytotoxicity and platelet aggregation inhibitory activity of a novel molecule isolated and characterized from mango ginger (Curcuma amada Roxb.) rhizome. J Biosci. 2010;35(2):231-40. https://doi.org/10. 1007/s12038-010-0027-1.

103. Mujumdar AM, Naik DG, Misar AV, Puntambekar HM, Dandge CN. CNS depressant and analgesic activity of a fraction isolated from an ethanol extract of curcumaamada rhizomes. Pharm Biol. 2004;42(7):542-6. https://doi.org/10.3109/13880200490893429.

104. Singh G, Singh OP, Maurya S. Chemical and biocidal investigations on essential oils of some Indian Curcuma species. Prog Crystal Growth Charact. 2002;45:75-81.

105. Singh S, Kumar JK, Saikia D, Shanker K, Thakur JP, Negi AS, Banerjee S. A bioactive labdane diterpenoid from Curcuma amada and its semisynthetic analogues as antitubercular agents. Eur J Med Chem. 2010;45(9):4379-82. https://doi.org/10.1016/j.ejmech.2010.06.006.

106. Ramachandran C, Lollett IV, Escalon E, Quirin KW, Melnick SJ. Anticancer potential and mechanism of action of mango ginger (Curcuma amada Roxb.) supercritical $\mathrm{CO}_{2}$ extract in human glioblastoma cells. J Evid Based Complementary Altern Med. 2015;20(2):109-19. https://doi.org/ $10.1177 / 2156587214563731$.

107. Jambunathan S, Bangarusamy D, Padma PR, Sundaravadivelu S. Cytotoxic activity of the methanolic extract of leaves and rhizomes of Curcuma amada Roxb against breast cancer cell lines. Asian Pac J Trop Med. 2014;7S1:S405-9. https://doi.org/10.1016/S1995-7645(14)60266-2.

108. Nguyen HC, Chen CC, Lin KH, Chao PY, Lin HH, Huang MY. Bioactive compounds, antioxidants, and health benefits of sweet potato leaves. Molecules. 2021;26(7):1820. https://doi.org/10.3390/molecules260718 20.

109. Mohanraj R, Sivasankar S. Sweet potato (Ipomoea batatas [L.] Lam)—a valuable medicinal food: a review. J Med Food. 2014;17(7):733-41. https://doi.org/10.1089/jmf.2013.2818.

110. Sugata M, Lin CY, Shih YC. Anti-inflammatory and anticancer activities of taiwanese purple-fleshed sweet potatoes (Ipomoea batatas L. Lam) extracts. Biomed Res Int. 2015;2015:768093. https://doi.org/10.1155/ 2015/768093.

111. Wang W, Li J, Wang Z, Gao H, Su L, Xie J, Chen X, Liang H, Wang C, Han Y. Oral hepatoprotective ability evaluation of purple sweet potato anthocyanins on acute and chronic chemical liver injuries. Cell Biochem Biophys. 2014;69:539-48. https://doi.org/10.1007/s12013-014-9829-3.

112. Akhtar N, Akram M, Daniyal M, Ahmad S. Evaluation of antidiabetic activity of Ipomoea batatas L. extract in alloxan-induced diabetic rats. Int J Immunopathol Pharmacol. 2018;32:2058738418814678. https:// doi.org/10.1177/2058738418814678.

113. Sun H, Zhang P, Zhu Y, Lou Q, He S. Antioxidant and prebiotic activity of five peonidin-based anthocyanins extracted from purple sweet potato (Ipomoea batatas (L.) Lam.). Sci Rep. 2018;8(1):5018. https://doi.org/10. 1038/s41598-018-23397-0.

114. Ayurvedic pharmacopoeia of India. Ayurvedic pharmacopoeia of India Part-1., 2. New Delhi, India: Ministry of Health and Family Planning, Department of Health, Government of India, 2001;183-184.

115. Pandey N, Yadav D, Pandey V, Tripathi YB. Anti-inflammatory effect of Pueraria tuberosa extracts through improvement in activity of red blood cell anti-oxidant enzymes. Ayu. 2013;34(3):297-301. https://doi. org/10.4103/0974-8520.123131.

116. Hsu FL, Liu IM, Kuo DH, Chen WC, Su HC, Cheng JT. Antihyperglycemic effect of puerarin in streptozotocin-induced diabetic rats. J Nat Prod. 2003;66(6):788-92. https://doi.org/10.1021/np0203887.

117. Gupta RS, Sharma R, Sharma A. Antifertility effects of Pueraria tuberosa root extract in male rats. Pharm Biol. 2004;42:3-9.

118. Srivastava S, Shree P, Pandey H, Tripathi YB. Incretin hormones receptor signaling plays the key role in antidiabetic potential of PTY-2 against STZ-induced pancreatitis. Biomed Pharmacother. 2018;97:330-8. https://doi.org/10.1016/j.biopha.2017.10.071.

119. Nagwani S, Tripathi YB. Amelioration of cisplatin induced nephrotoxicity by PTY: a herbal preparation. Food Chem Toxicol. 2010;48(8-9):2253-8. https://doi.org/10.1016/j.fct.2010.05.057.

120. Aruna MR, Mukesh Kumar DJ, Palani P, Senbagam D, Senthilkumar B. Effects of Pueraria tuberosa Linn Hydroalcoholic Tuber Extract on Expression of Apoptosis Associated Proteins in HT - 29 Human Colon Carcinoma Cell Line. Int J Curr Microbiol Appl Sci. 2018;7(6):3863-73. https://doi.org/10.20546/ijcmas.2018.706.455.

121. Basavaraj P, Shivakumar B, Shivakumar H. Evaluation of Anticonvulsant activity of alcoholic extract of tubers of Pueraria Tuberosa (Roxb). Adv Pharmacol Toxicol. 2011;12:1-9.

122. Verma SK, Jain V, Vyas A, Singh DP. Protection against stress induced myocardial ischemia by Indian kudzu (Pueraria tuberosa) — a case study. J Herb Med Toxicol. 2009:3(1):59-63.

123. Patel RV, Mistry BM, Shinde SK, Syed R, Singh V, Shin HS. Therapeutic potential of quercetin as a cardiovascular agent. Eur J Med Chem. 2018;15(155):889-904. https://doi.org/10.1016/j.ejmech.2018.06.053.

124. Shukla R, Banerjee S, Tripathi YB. Antioxidant and Antiapoptotic effect of aqueous extract of Pueraria tuberosa (Roxb. Ex Willd.) DC. On streptozotocin-induced diabetic nephropathy in rats. BMC Complement Altern Med. 2018;18(1):156. https://doi.org/10.1186/s12906-018-2221-x. 
125. Kumar S, Das G, Shin HS, Patra JK. Dioscorea spp. (a wild edible tuber): a study on its ethnopharmacological potential and traditional use by the local people of similipal biosphere reserve, India. Front Pharmacol. 2017;8:52. https://doi.org/10.3389/fphar.2017.00052.

126. About Chhattisgarh. http://cgtrti.gov.in/AboutCg.html\#: :text=The\% 20area\%20mainly\%20inhabits\%20tribes,\%2C\%20Gond\%2C\%20Baiga\% 2C\%20Agaria. Accessed 9 Aug 2021

127. Beck NR, Samal P. Traditional medicinal plants used by the tribes and rural People of Bilaspur District, Chhattisgarh (India). Res J Pharm Technol. 2012;5(10):1281-2.

128. Janghel V, Patel P, Chandel SS. Plants used for the treatment of icterus (jaundice) in Central India: a review. Ann Hepatol. 2019;18(5):658-72. https://doi.org/10.1016/j.aohep.2019.05.003.

129. Mihiranie $\mathrm{S}$, Jayasinghe JK, Jayasinghe CVL, et al. Indigenous and traditional foods of Sri Lanka. J Ethn Food. 2020;7:42. https://doi.org/10. 1186/s42779-020-00075-z.
130. Halawa A. Analysis of the health effects of the transition of traditional Chinese food on the emergence of nontraditional eating behaviors. J Ethn Food. 2021;8:14. https://doi.org/10.1186/s42779-021-00087-3.

131. Hawkes C, Harris J, Gillespie S. Urbanization and the nutrition transition. In Global Food Policy Report. 2017;4:34-41. Return to ref 12 in article

132. Pollan M. Food rules: an eater's manual: penguin group USA; 2009 .p.89

\section{Publisher's Note}

Springer Nature remains neutral with regard to jurisdictional claims in published maps and institutional affiliations.
Ready to submit your research? Choose BMC and benefit from:

- fast, convenient online submission

- thorough peer review by experienced researchers in your field

- rapid publication on acceptance

- support for research data, including large and complex data types

- gold Open Access which fosters wider collaboration and increased citations

- maximum visibility for your research: over 100M website views per year

At BMC, research is always in progress.

Learn more biomedcentral.com/submissions 